Volcanogenic processes and petrogenesis of the early Pleistocene andesitic-dacitic Maungatautari composite cone, Central Waikato, New Zealand.

M.L. Prentice*, A. Pittari, S.L.L. Barker ${ }^{1}$ and V.G. Moon

Schoool of Science, University of Waikato, Hamilton, New Zealand

*School of Science, Private Bag 3105 Hamilton, 3240, New Zealand;

prenticelm@gmail.com

${ }^{1}$ Present address: School of Natural Sciences (Earth Sciences), University of Tasmania, Private Bag 79, Hobart, TAS 7001 


\title{
Volcanogenic processes and petrogenesis of the early Pleistocene andesitic-dacitic Maungatautari composite cone, Central Waikato, New Zealand.
}

\author{
Abstract \\ Maungatautari is an extinct, andesitic-dacitic composite cone situated $70 \mathrm{~km}$ \\ northwest of the Taupo Volcanic Zone, New Zealand. This study examines the \\ volcanic history and petrologic evolution of Maungatautari using field mapping, \\ descriptions and petrography of pyroclastic successions and lavas, combined with \\ whole rock elemental and isotope analyses of selected lavas. Lavas consist of \\ non-vesicular labradorite, pyroxene and hornblende andesites and hornblende \\ dacites with a small cone of olivine basalt located at Kairangi, $7 \mathrm{~km}$ to the \\ northwest. Whole rock geochemical and strontium and neodymium analyses \\ demonstrate that these lavas were derived from at least three distinct mantle-melt \\ sources. Mass-wasting processes continue to shape the mountain post volcanic \\ activity and include catastrophic failure of the north-eastern flank which \\ produced a $0.28 \mathrm{~km}^{3}$ rock avalanche deposit. This study considers Maungatautari \\ to reflect andesitic volcanism occurring along the edge of the continental tip of \\ the Colville volcanic arc c. 2 Ma.
}

Keywords: Maungatautari; geology; volcanism; geochemistry; Waikato; New Zealand

\section{Introduction}

The Taupo Volcanic Zone (TVZ) in the North Island of New Zealand is the most recent manifestation of arc-related volcanism which has migrated south and eastwards over the past 16 million years (Wilson and Rowland 2016). This migration is represented by deeply eroded volcanic centres of early-Miocene to Pleistocene age, which crop out from Northland, along the Coromandel Peninsula and into Tauranga and the western and central Waikato Region (Briggs et al. 1989; Hayward et al. 2001). In addition to arcrelated volcanism, spatially and temporally related intraplate basaltic fields are also 
spaced throughout the upper North Island (Briggs and McDonough 1990).

Maungatautari is an extinct, andesitic-dacitic composite cone situated $35 \mathrm{~km}$ southeast of Hamilton within the Waipa District, Waikato (Fig. 1). With a single radiometric age date of $1.8 \mathrm{Ma}$ (Robertson 1983), activity at Maungatautari was contemporaneous with subduction-related volcanism of the nearby Alexandra Volcanics and the early Taupo Volcanic Zone. While volcanism at Maungatautari was previously addressed in the context of the broader volcanic geology of the Waikato region (Olson 1950; Kear 1964; Cole 1978), the only dedicated volcanic study conducted by Briggs (1986a) provided insight into the chemical composition and origin of the magmas.

Here we examine the volcanic history and petrologic evolution of Maungatautari using geological and geomorphological mapping, facies analysis and petrography of new exposures combined with whole rock elemental and isotope analyses of selected lavas. This paper integrates geological, geomorphological, volcanological and geochemical aspects of the mountain into one study to build on previous work, re-evaluate the volcanic history of Maungatautari and provide new insights into how Maungatautari relates to Early Pleistocene volcanism elsewhere in the Waikato region.

\section{Geomorphology and regional geology}

Roughly circular in shape, Maungatautari is $6-8 \mathrm{~km}$ in diameter at its base. Rising to 797 $\mathrm{m}$ above sea level, it is the second highest volcano of the Waikato region after Mount Pirongia of the Alexandra Volcanic Group (Fig. 1). The mountain is typified by sharply convex ridgelines with steep $\left(>25^{\circ}\right)$ slopes in the upper portions of the mountain grading down flank to more rounded, gentle to moderate $\left(6-25^{\circ}\right)$ slopes. The flanks are dissected by deeply incised gullies, with those of the Ruapeka and Mangapiko and the Mangaohoi and Mangakara streams (Fig. 2) on the northwestern and southern slopes, respectively, being especially broad and well developed. The volcanic vents of Kairangi, Oreipunga 
and an inferred eroded summit vent centred near Maungatautari Trig display a distinct northwest alignment, a trend well recognised in the nearby Alexandra and Kiwitahi volcanic groups.

Maungatautari overlies Jurassic Manaia Hill group rocks of the Waipapa Terrane and abuts a range of the same rocks immediately to the west (Fig. 2; Leonard et al. 2010). To the north, east and south, it is surrounded by a thick $(>100 \mathrm{~m})$ ignimbrite plateau which overlies the lowermost flanks of the mountain and is comprised of deposits of the Pakaumanu Group, which includes the Rocky Hill and Kidnappers (Raepahu Formation) and the Ahuroa (Mangaokewa Formation) ignimbrites, originating from the Mangakino caldera to the southeast (Olissoff 1981; Leonard et al. 2010). A new geological map, presented here (Fig. 2), is mostly consistent with that of Leonard et al. (2010), except that the extended ring plain of lahar deposits of Healy et al. (1964) and Leonard et al. (2010) which have been mapped to the north and encircled the mountain has been replaced here with undifferentiated Pakaumanu Group Ignimbrites. This variation from previous geological maps reflects field evidence of channelised lahar deposits, consistent with Briggs (1986a) and stratigraphic logs of water bores from Waikato Regional Waikato Regional Council (n.d).

Much of the Maungatautari edifice remains undifferentiated due to limited outcrop exposure and as such the correlation of units has not been attempted. Observed outcrops consist of a variety of volcanic and mass wasting deposits, including lavas, volcaniclastic and hydrothermal breccias, and pyroclastic deposits.

\section{Maungatautari Lavas}

Across the Maungatautari edifice, exposed lavas are generally non-vesicular, porphyritic andesites and dacites with varying amounts of plagioclase, clinopyroxene, orthopyroxene and hornblende phenocrysts and xenoliths. Olivine basalt was obtained from the nearby 
cone of Kairangi, located $7 \mathrm{~km}$ to the northwest. Kairangi cone is compositionally distinct from the range of lava compositions found across Maungatautari but has been included in this study as the petrogenetic relationship between the two volcanoes has not previously been fully explored. An outcrop of hornblende dacite located at Rocky Outcrop (Fig. 2) represents a late-stage dike, consistent with the radial dikes of Little Rock, Hook Nose (Olson 1950) and Te Akatarere (Briggs 1986a).

\section{Petrography and mineralogy}

The highly porphyritic Maungatautari lavas often display seriate textures with phenocrysts occasionally clustered as glomerocrysts. Whole-rock phenocryst abundances range from $22 \%$ to $53 \%$ and include plagioclase, orthopyroxene, clinopyroxene, hornblende, and opaque Fe-Ti oxides. In contrast, the dominant phenocryst within the Kairangi Basalt is olivine. Samples have been differentiated using modal composition and $\mathrm{SiO}_{2}$ content based on previous classifications by Cole (1978) and Briggs (1986a). Olivine basalt, found exclusively at Kairangi cone, contains abundant olivine phenocrysts that are visible in hand specimens. The andesites and dacites of the Maungatautari volcano sensu stricto are separated into: labradorite andesites, defined as containing total modal plagioclase $>$ pyroxene; pyroxene andesites have total modal pyroxene $>15 \%$; and hornblende andesites and dacites containing significant hornblende also visible in hand specimen. Representative modal analyses of lavas sampled in this study are presented in Table 1.

Phenocrysts are set in a fine grained, plagioclase lath-dominated groundmass with intergranular, intersertal, trachytic and hyalopilitic textures. Plagioclase is the most abundant phenocryst phase in all Maungatautari lavas, comprising from 18 to $37 \%$ of the whole rock with sizes typically $1.5-2 \mathrm{~mm}$. A few megacrysts, were found to be as large 
as $2.5-3 \mathrm{~mm}$ in size. Oscillatory zoning and sieve-textures are common reflecting multiple crystallization histories.

The abundance of total pyroxene ranges from $<1-18 \%$ of the whole rock with orthopyroxene always subordinate to clinopyroxene. Crystals of both pyroxenes are euhedral to subhedral with sizes typically in the range of $0.5-1.25 \mathrm{~mm}$, with rare crystals up to $2 \mathrm{~mm}$ observed.

Hornblende occurs predominently in Maungatautari dacites, but it is also found in some andesites, indicative of the hydrous nature of the magmas. Crystals are elongate and are $<2.5 \mathrm{~mm}$ in length with modal abundances of up to $19 \%$. Many crystals show alteration to fine-grained aggregates of Fe-oxides and/or pyroxene with some being completely pseudomorphed. This style of crystal decomposition is related to decompression related dehydration as the melt ascends through the upper crust prior to, or during eruption (Gill 2010).

\section{Pyroclastic deposits}

This study is the first to document a record of explosive volcanism at Maungatautari. Two successions named Quarry \#34 (Q34) and the Summit Quarry (SQ) (Fig. 2) were divided in the field into stratigraphic units (QT1-QT9 at Q34, Fig. 3; SQ1-SQ3 at SQ,

Fig. 4), defined as distinct identifiable depositional layers with clear textural or compositional boundaries. Units were assigned one of five different facies types based on textural and structural differences (Facies A-E below).

\section{Facies A-Massive, moderately-poorly sorted, fine to coarse lapilli tuff}

Facies A is characterised by massive, moderately to poorly sorted fine to coarse lapilli tuff and comprises more than half of the stratigraphic thickness of the successions at each site and the entire thickness of units QT1, QT3, QT5, QT8 (Q34, Fig. 3) and SQ1 (SQ, 
Figs. $4,5 b$ ). Units vary from $0.2 \mathrm{~m}$ to up to $2.6 \mathrm{~m}$ in thickness, with the thicker units consistently found within the lower half of the successions. The upper stratigraphic units of this facies are finer-grained than the lower units and consisted of fine to medium lapilli tuff.

Facies B - Laminated to very thinly bedded crystal and lithic-rich coarse tuff and very-fine lapilli

Facies $\mathrm{B}$ consists of laminated $(<1 \mathrm{~cm}$ in thickness) to very-thinly bedded $(1-2 \mathrm{~cm})$, crystal- and lithic-rich coarse tuff and very-fine lapilli which comprises three stratigraphic units within the Q34 succession: unit QT2, 0.4 m thick; unit QT7, 0.35 m thick; and unit QT9, 0.7 m thick (Figs. 3,5a).

Parallel stratification of facies B within unit QT2 occurs as very thin beds up to 2 $\mathrm{cm}$ thick. The maximum thickness of this unit is $0.4 \mathrm{~m}$, however, the upper contact undulates which causes the thickness of this unit to be irregular across the exposure ranging from $0.2 \mathrm{~m}$ to $0.4 \mathrm{~m}$. The internal stratification of facies B within units QT7 and QT9 forms alternating coarse laminations, rather than thin beds, of coarse tuff and fine lapilli and both units display normal grading.

\section{Facies $C$ - Massive coarse tuff}

The two very thin beds $(0.015-0.03$ m thick) of facies $\mathrm{C}$, were characterised as laterally continuous, red-coloured, massive, well sorted coarse tuff (Fig. 5a). This facies was only present at Q34 and directly overlies units of facies A (Fig. 3).

\section{Facies D-Non-welded massive lapilli-block tuff}

This facies comprises SQ1 of the SQ succession (Fig. 4) and consists of a red-coloured, matrix-supported, non-welded, massive lapilli-block tuff (Fig. 5c). It is distinguished from the massive lapilli tuff of facies A by a significantly higher proportion of angular 
blocks and ash matrix, estimated in the field to be $5-7 \%$ and $60-70 \%$ of the bulk deposit respectively.

Facies E-Massive and poorly sorted silty sandy gravel, with reversely graded blocks

The upper stratigraphic interval at SQ (unit SQ3, Figs. 4, 5d), consists of reversely graded blocks of non-vesicular, porphyritic hornblende-rich andesitic-dacitic lavas within a massive and poorly sorted (silt-pebble sized) matrix. The lensoidal geometry of this unit, lack of juvenile clasts, distinctive matrix texture and the distinct fines-rich base distinguish this facies from those previously described.

\section{Componentry}

Componentry was determined by field and petrographic observation. The major components of the eruptive deposits are lapilli to block sized pyroclasts comprising a mixture of (i) crystal-rich, vesicular and non-vesicular juvenile clasts, (ii) dense lithics of angular fresh, weathered and/or hydrothermally-altered andesite-dacite lava, and (iii) within units QT1 and QT3 at Q34, sub-rounded fragments of poorly sorted fine-grained sandstones. Clasts are contained within a non-welded, crystal- and lithic-rich coarse tuff matrix, except for facies E which is more poorly sorted.

Juvenile clasts include both vesicular and non-vesicular, hornblende-rich clasts which range from $2-3 \mathrm{~cm}$ to $20 \mathrm{~cm}$ in diameter. In both types, the dominant phenocryst mineral phases are plagioclase along with hornblende, rare pyroxenes and disseminated opaque minerals. Lithics include angular fragments of fresh, weathered and/or hydrothermally altered, dense, porphyritic andesite-dacite lavas and greywacke. Individual clast sizes range from $1-2 \mathrm{~cm}$ to up to $\sim 8 \mathrm{~cm}$ or $21 \mathrm{~cm}$ in diameter. Lithics of greywacke were found within units QT1 and the lower half of unit QT3, 1-2 m above 
ground level at Q34. Lithics of basement lithology were not observed within the deposits at SQ.

\section{Rock avalanche deposits}

On the northeastern flank of Maungatautari (Fig. 2), a $0.28 \mathrm{~km}^{3}$ rock avalanche is characterised by a horse-shoe-shaped, steep-sided break-away scarp and large hummocks which cover a depositional area approximately $1.6 \mathrm{~km}^{2}$ in size, extending to the northeast. The northern and southern deposit boundaries mirror the scarp of the mountain with the hummocks becoming obscured east of Roberts Road. Internally hummocks consist of poorly-sorted blocks of porphyritic andesite within a finer grained matrix of similar lithology (Fig. 6). Large angular to sub-angular blocks up to $2 \mathrm{~m}$ wide by 3-4 $\mathrm{m}$ long consisted of dense, feldspar-rich porphyritic andesite with coarse jointing. Some andesite blocks contained abundant, sub-spherical $<10 \mathrm{~cm}$-sized clasts of hornblende-rich, yellow xenoliths, interpreted by Briggs (1986a) to be cognate xenoliths. A few smaller blocks, however, were found to be composed of basement-derived chipwacke. The presence of basement lithologies within the rock avalanche deposit suggests that on this side of Mauungatautari, the basement is relatively shallow and was excavated from the scarp area along with andesite during flank failure. Hummocks are covered by $0.5 \mathrm{~m}$ of a redorange, well-developed soil overlain by $\sim 15 \mathrm{~cm}$ of dark brown organic rich soil. The head of the collapse scarp is obscured by a steep talus slope, comprised of material that failed to be incorporated into the main flow, and accumulated within the rock avalanche source area. It extends approximately $700 \mathrm{~m}$ into the centre of the excavated area, and is overlain by subsequent rock fall, slide and debris flow deposits. 


\section{Volcaniclastic Breccias}

Localised outcrops of volcaniclastic breccias occur within stream valleys throughout the upper and lower flanks of the edifice. The breccias are non- to reversely-graded and composed of angular to sub-rounded cobbles and boulders of non-vesicular, porphyritic hornblende-rich andesitic-dacitic lavas within a massive and poorly sorted (silt-pebble sized) matrix. Interpreted as deposits of debris flows, these units are localised and across the lower slopes are stratigraphically intercalated with ignimbrites of the Pakaumanu Group (Olissoff 1981).

\section{Hydrothermally-altered zones}

A localised area of hydrothermally-altered andesite is located within the headwaters of the Mangakara Stream in a pit excavated in the late $19^{\text {th }}$ or early $20^{\text {th }}$ century during gold prospecting (Fig. 2). In-situ fluid-assisted brecciation has fragmented the host lava creating a mosaic-like texture of angular clasts, $1-4 \mathrm{~cm}$ in size with relict porphyritic texture. Clasts show little rotation and fit together in a jigsaw-like fashion and are surrounded by an alteration matrix consisting of a fine-grained crystalline quartzrich medium. Alteration minerology consists of cristobalite, alunite and kaolinite, characteristic of advanced argillic hydrothermal alteration representative of a lowsulfidation hydrothermal system (Prentice 2017). The advanced argillic alteration passes outwards into an outer zone of propylitic alteration. This is characterised at Maungatautari by the uncharacteristic presence of albite, which was found in samples obtained from the outer portion of the lava flow away from this intensely altered zone. A similar system occurs at the Ketetahi springs on the upper flanks of Mt Tongariro where volatiles degassing from deep underlying boiling magmatic fluids, ascend and condense into the meteoric waters of the water table, creating acidic waters, which cause severe leaching 
and advanced argillic alteration expressed by surface manifestations of highly acidic fumaroles and/or hot springs. (Simmons et al. 2005).

\section{Geochemistry of lavas}

\section{Analytical methods}

Major element geochemical analysis was conducted using the Bruker S8 Tiger X-ray fluorescence spectrometer at the University of Waikato. Major element abundances cited in the text and shown on diagrams were recalculated to total $100 \mathrm{wt} \%$ on an anhydrous basis. Trace and rare earth elemental analysis employed LA-ICP-MS where samples were prepared using the method outlined by Eggins (2003), which utilises lithium borate glass fusion beads following standard preparation procedures for XRF analysis. Trace elements that were determined by LA-ICP-MS are listed in Table 2. Data was acquired using static spot analyses with a laser beam diameter of $30 \mu \mathrm{m}(60 \mu \mathrm{m}$ for NIST standards). A summary of LA-ICP-MS analytical parameters is provided as supplementary information. Abundances of $\mathrm{SiO}_{2}$ from XRF analyses, in addition to NIST 612 were used to calibrate LA-ICP-MS results. Three international MPI-Ding standards StHs6/80-G and ML3B-G were used to ensure data quality as they are of andesitic and basaltic composition respectively, which is similar to the rock types found at Maungatautari. Mean replicate abundances of $\mathrm{Sr}, \mathrm{Zr}, \mathrm{Nb}, \mathrm{Ba}, \mathrm{La}, \mathrm{Ce}, \mathrm{Pr}, \mathrm{Sm}$, Dy,Ho, Th and $\mathrm{U}$ are within \pm c. $5 \%$ of the recommended values (Jochum et al. 2005) (Fig. 7), whereas Sc, V, Rb, Y, $\mathrm{Cs}, \mathrm{Eu}, \mathrm{Gd}, \mathrm{Er}, \mathrm{Yb}$ and $\mathrm{Pb}$ are within \pm c. $10 \%$ than the Jochum et al. (2005) values. Measurements of Nd of StHs6/80-G are higher by ca 25-35\%, and Sn for both standards demonstrated poor precision with values at least $50 \%$ higher than those stated by Jochum et al. (2005). 
Five samples were analysed for $\mathrm{Sr}$ and $\mathrm{Nd}$ isotopes by the Geochemistry Laboratory at Victoria University of Wellington. Following the concomitant isolation procedure of Pin et al. (2014), the Sr and Nd fractions were analysed for isotopic ratios by thermal ionization mass spectrometry (TIMS). Laboratory averages for the NBS 987 and La Jolla standards were ${ }^{87} \mathrm{Sr} /{ }^{86} \mathrm{Sr}=0.710256 \pm 0.000006(2 \sigma)$ and ${ }^{143} \mathrm{Nd} /{ }^{144} \mathrm{Nd}=$ $0.511847 \pm 0.000003(2 \sigma)$ respectively.

Representative geochemical analyses are listed in Table 2. The full dataset is available as online supplementary data.

\section{Results}

Lava compositions range from basalt at Kairangi, to med-high $\mathrm{K}$ andesites and dacites (57-66.45 wt. \%, normalised to $100 \%$ volatile free) across the Maungatautari edifice. No samples of basalt or basaltic andesite composition were found across the Maungatautari edifice.

With increasing $\mathrm{SiO}_{2}$ content, there is a progressive decline in abundance of $\mathrm{Fe}_{2} \mathrm{O}_{3}, \mathrm{CaO}, \mathrm{MgO}$ and $\mathrm{TiO}_{2}$, and increases in $\mathrm{Na}_{2} \mathrm{O}$ and $\mathrm{K}_{2} \mathrm{O}$, consistent with the trends described by Briggs (1986a) (Fig. 8). Compatible trends within the trace elements Sc and $\mathrm{Sr}$ relate to the crystallisation of pyroxenes and the substitution for $\mathrm{Ca}$ in plagioclase respectively. Low concentrations of $\mathrm{Ni}(5-25 \mathrm{ppm})$ are also consistent with andesites derived via fractional crystallisation (Winter 2014).

The eruption of high magnesium number $(\mathrm{Mg} \#)$ lavas has occurred at numerous North Island volcanoes (Cole and Teoh 1975; Froude and Cole 1985; Booden et al. 2010). Defined by Kelemen et al. (2013), high-Mg\# andesites are rocks of $>54$ wt. $\% \mathrm{SiO}_{2}$ and Mg\# $>50$. The Mg\# of Maungatautari lavas varies between 30 and 49 (Fig. 9) and therefore cannot be classified as high-Mg andesites. 
A primordial mantle-normalised multielement diagram is shown in Fig. 10. There is a distinct decoupling of the large ion lithophile (LIL) elements $\mathrm{K}, \mathrm{Rb}$, Cs and the high field strength (HFS) elements $\mathrm{Zr}, \mathrm{Nb}, \mathrm{Th}, \mathrm{U}$ and rare Earth elements. Unusually high MORB normalised REE values (Fig. 11) coupled with negative Ce anomalies and high Y concentrations (93-166 ppm) were obtained from three low-silica hornblende andesites which appeared fresh in both hand specimen and thin section. This phenomenon has also been documented within basalts from Hawaii (Roden et al. 1984) and southeast Australia (Price et al. 1991), along with some basaltic to andesitic samples from the Kiwitahi Volcanics of the Coromandel Volcanic Zone (Kuschel and Smith 1992) and attributed to weathering and cryptic hydrothermal alteration respectively. In contrast, Neal and Taylor (1989) suggests it reflects the recycling of crustal materials within the upper mantle. The samples in this study were collected from opposing sides of the mountain removed from any locations of known hydrothermal activity and show no evidence of weathering or major element mobility. As such, the data has been retained for the purpose of this study.

Isotopic ratios for samples from across the main edifice (GF006, MRd020, ORE039b and ORE040) show little spread and are comparable to those of the Coromandel Volcanic Zone (Fig. 12). The hornblende andesite and dacite (samples ORE040 and ORE039b respectively) have lower $\mathrm{Nd}$ and higher $\mathrm{Sr}$ ratios than the pyroxene and labradorite andesites and are displaced towards typical compositions of the Waipapa terrane metasedimentary basement rocks.

The olivine basalt from Kairangi (KSC001) is consistently isolated from the general trends described above and plot as alkali basalts using the $\mathrm{Nb} / \mathrm{Y}$ classification diagram of Winchester and Floyd (1977). A distinction is also observed within the REE and multi-element diagrams (Figs 9 and 10) where the basalt is not as enriched in LIL elements and has a less pronounced negative $\mathrm{Nb}$ anomaly. ${ }^{143} \mathrm{Nd} /{ }^{144} \mathrm{Nd}$ and ${ }^{87} \mathrm{Sr} /{ }^{86} \mathrm{Sr}$ 
isotopes are significantly higher at 0.512849 and 0.703850 , respectively, which overlap with the Alexandra Volcanic Group and approach the intraplate magmas of the Okete field (Fig. 12). Thus, the olivine basalt is not petrogenetically related to the fractionating andesite and dacites of the Maungatautari system.

\section{Discussion}

\section{Eruption styles}

The products of effusive volcanism dominate preserved deposits across the Maungatautari edifice as they are often more resistant to erosion than those from explosive eruption styles. However, the two pyroclastic successions (Q\#34 and the SQ) described here have contrasting eruptive histories. The summit quarry consists of a block and ash flow deposit (unit SQ1) resulting from the collapse of a lava dome, followed by an explosive eruption which generated a pyroclastic density current (PDC) (unit SQ2) and, later, a lahar (SQ3). In contrast, the succession at Q\#34 depicts multiple PDC events (units QT1, QT2, QT3, QT5, QT7, QT8 and QT9) as a series of PDCs, some with upper co-fall deposits (units QT4 and QT6). The presence of basement lithics within units QT1 and QT3 represents a deeper fragmentation depth within the underlying Jurassic strata for the eruption associated with Q\#34.

These successions demonstrate a complex, multiple phase eruption history which included cycles of dome growth and collapse, and the repeated production of eruption columns from associated vulcanian to sub-plinian style activity which created numerous PDCs. This activity was likely centred at a now-eroded summit vent and occurred over a period of days, weeks or months. 


\section{Petrogenesis of magmas}

The decoupled LIL/HFS pattern and $\mathrm{Nb}$ trough in the mantle-normalised multi-element diagram (Fig. 10), is a distinctive feature of subduction zone magmas. The progressive decline in abundance of $\mathrm{Fe}_{2} \mathrm{O}_{3}, \mathrm{CaO}, \mathrm{MgO}$ and $\mathrm{TiO}_{2}$, with concurrent increases in $\mathrm{Na}_{2} \mathrm{O}$ and $\mathrm{K}_{2} \mathrm{O}$ with increasing $\mathrm{SiO}_{2}$ content, implies, at least qualitatively, that the evolution of Maungatautari lavas was dominated by the fractional crystallisation of a parent magma. Fractionation modelling by Briggs (1986a) highlights that magma petrogenesis at Maungatautari and its subsequent evolution is likely to be complex. Basalts have yet to be found at Maungatautari but may have been emplaced as plutonic rocks within the middle and upper crust. Primitive magmas are considered to have $\mathrm{Mg \#}>60$ and while primitive basalts are found in a variety of plate tectonic settings, primitive andesites are largely confined to continental arcs (Kelemen et al. 2013). With Mg numbers of between 30 and 49, Maungatautari lavas are not primitive, nor can they be classified as high-Mg\# andesites (Fig. 9). As such, they are considered here to be evolved magmas following Kelemen et al. (2013), who uses the assumption that crystallization processes always produce a lower $\mathrm{Mg} \#$ in derivative liquids, when compared with parental liquids.

Eleven samples have $\mathrm{Mg} \#$ of between $>46-49$ and are considered to represent least evolved magmas which consist of pyroxene andesites and three samples of hornblende andesite. The hypothesis that these pyroxene andesites represent least evolved magmas is supported by the fractionation models of Briggs (1986a) which produced acceptable fits for the fractionation of a labradorite andesite from a pyroxene andesite parent melt. The high Mg\# of these rocks may therefore reflect the lack of olivine crystallisation from a primitive andesitic melt, or simply be the product of abundant phenocrysts of clinopyroxene (Kelemen et al. 2013). As neither clinopyroxene nor olivine were present within the hornblende andesites, these mineral phases are not contributing to the high $\mathrm{Mg \#}$ of these samples in any way. A slight negative Eu anomaly amongst the labradorite 
andesites and dacites (Fig. 11) reflects plagioclase fractionation and is consistent with the concept that pyroxene andesites are representative of least evolved melts at Maungatautari, from which such an anomaly is absent.

The presence of a deep $(>70 \mathrm{~km})$ garnet-bearing source rock is suggested by the depletion of HREE and $\mathrm{Y}$ in which they are strongly compatible and retained at the expense of the melt (Gill 2010; Winter 2014). The low-SiO 2 hornblende andesites have LIL element concentrations consistent with other samples from the main Maungatautari edifice, but are more enriched in the heavy REEs and Y (Figs 10,11) which is more reflective of a relatively shallow, source rock with minimal garnet crystallization.

The Kairangi olivine basalts have markedly different multi-element patterns being less enriched in LIL elements with a less pronounced negative $\mathrm{Nb}$ anomaly (Fig. 10). The smoother pattern in the multi-element diagrams is more reflective of intraplate over subduction-related melts (Winter 2014) and excludes the Kairangi olivine basalt from being the primary magma for Maungatautari.

\section{Local and regional geochemical affinity}

Currently, Maungatautari is considered as a subduction-related volcano situated behind the volcanic front active approximately 1.8 Ma (Briggs 1986a). However, the trace and rare earth element geochemical data presented in this study have provided new insight into the relationship between Maungatautari and the other volcanic centres active c. 2 Ma.

The main fractionating system that produced magmas at Maungatautari have multi-element and REE patterns that bear a striking resemblance to those from the Coromandel Volcanic Zone and Ruapehu (Fig. 13). A similar pattern is also seen within the Alexandra and Taranaki magmas with positive anomalies in $\mathrm{Ba}$ and $\mathrm{Sr}$ being attributed to crustal level processes influencing subduction magma genesis set behind the volcanic arc front (Price et al. 2016). With negative $\mathrm{Ba}$ and $\mathrm{Sr}$ anomalies, Maungatautari 
multi-element and REE patterns and $\mathrm{Sr}$ and $\mathrm{Nd}$ isotopes, best reflect those from Coromandel Volcanic Zone and Ruapehu. They are therefore interpreted to represent volcanism associated with the main volcanic arc, which extended south from Tauranga to Maungatautari into continental New Zealand during this time (Fig. 14), and are inferred to represent the southernmost expression of arc-related magmatism within the North Island of New Zealand at this time.

The near-by Alexandra Volcanics consisted of contemporaneous, behind-arc subduction-related volcanism, the nature of which was first proposed by Briggs et al. (2013). The alkali olivine basalt at Kairangi displays a distinct intraplate signature and is therefore unrelated to magmatism at Maungatautari although the exact temporal relationship between the two magmatic series remains uncertain as the date range for Maungatautari volcanism remains poorly constrained. The coeval occurrence of intraplate alkali basalts alongside subduction-related magmas is well documented within the nearby Alexandra and Okete volcanic groups (Briggs et al. 1989; Briggs and McDonough 1990), although the mechanisms which result in the occurrence of two contrasting magma series within a clearly convergent tectonic setting remains uncertain.

\section{Interpretation of the volcanology and evolution of Maungatautari}

Age data for Maungatautari is limited and as such, the volcanic evolution of Maungatautari area is based on the stratigraphic relationships between the underlying basement rocks, the Maungatautari volcanic succession and the onlapping ignimbrite succession and mass wasting events.

Early volcanism within the Maungatautari area included the eruption of alkali olivine basalt 2.62 Ma (Briggs et al. 1989) to produce the small basalt cone of Kairangi which sits on uplifted and eroded Jurassic Manaia Hill group rocks of the Waipapa Terrane. The centre of volcanism then shifted $7 \mathrm{~km}$ southeast where, over time, the 
repeated eruption of intercalated small flows and domes of viscous andesitic-dacitic lavas and pyroclastic deposits from vulcanian to possibly sub-plinian eruption styles formed the roughly circular edifice of Maungatautari which is dated at c. $1.8 \mathrm{Ma}$ (Robertson 1983). An eruption of dacitic magma on the eastern flank led to the development of Oreipunga Cone. Thermal energy and magmatic fluids provided by the underlying magmatic system interacted with meteoric water to produce acidic fumaroles and hot springs on the upper slopes of the mountain in what is now the headwaters of the Mangakara Stream. Eventually, volcanism at Maungatautari ceased as activity shifted east to the newly formed Taupo Volcanic Zone. The eruption of ignimbrites from the Mangakino caldera, located to the southeast, resulted in the deposition of the plateau surface, underlain by ignimbrites, which now surrounds Maungatautari. The timing of the rock avalanche event in the northeast corner is poorly constrained, but the lack of edifice reconstruction and absence of ignimbrites over or between hummocks suggests it occurred within the last one million years after both the volcanic activity at Maungatautari had ceased and the ignimbrite plateau had been emplaced. The ongoing erosion of Maungatautari continues to shape the remains of the edifice present today.

\section{Conclusions}

Maungatautari is an andesitic-dacitic composite cone which overlies and abuts, on its western side, Jurassic Manaia Hill group rocks of the Waipapa Terrane. The northern, eastern and southern lowermost flanks are onlapped by ignimbrites derived from the Mangakino caldera to the southeast, which forms a plateau surface that buries much of the volcanic ring plain.

Lavas at Maungatautari were derived from at least three distinct mantle-melt sources with most andesites and dacites being petrogenetically related and associated with the fractionation of subduction-related, deep, garnet-bearing, depleted mantle source 
rock. In contrast, the low $\mathrm{SiO}_{2}$ hornblende andesites and Kairangi olivine basalt are derived from a shallower upper mantle (garnet-free) source rock and an area of deeper enriched mantle, respectively. Eruption styles at Maungatautari include the effusion of lava flows and domes, and vulcanian to sub-plinian explosive eruptions which produced numerous PDCs. An isolated area of hydrothermal activity on the upper flanks has modified the volcanic rocks in this area.

Catastrophic failure of the northeastern flank produced a $0.28 \mathrm{~km}^{3}$ rock avalanche deposit characterised by large hummocks that cover a depositional area approximately $1.6 \mathrm{~km}^{2}$ in size, and associated landslide scarp.

Volcanism at Maungatautari is interpreted to be part of the Colville volcanic arc, which extended south from Tauranga to Maungatautari into continental New Zealand c. $2 \mathrm{Ma}$. The alkali olivine basalt at Kairangi is more reflective of intraplate over subduction-related melts and is unrelated to magmatism at Maungatautari.

\section{Acknowledgements}

Funding for this study was provided by a UOW Masters Research Scholarship. MLP gratefully acknowledges the Waipa District Council, Maungatautari Ecological Island Trust (MEIT), Ngāti Korokī Kahukura along with Ruakawa, Tainui and Ngāti Hauā for granting consent for this study to take place within the confines of the reserve. Practical support within the sanctuary was provided by James Matthews and Craig Laxon. Thank you also to Bill Garland, John Scott and Mo who provided unrestricted access to private land. We thank the UOW School of Sciences technical staff for their expertise and guidance and Bruce Charlier (Victoria University of Wellington) for isotope data. 


\section{References}

Booden MA, Smith IEM, Mauk JL, Black PM. 2010. Evolving volcanism at the tip of a propagating arc: The earliest high-Mg andesites in northern New Zealand. Journal of Volcanology and Geothermal Research. 195(2-4):83-96.

Booden MA, Smith IEM, Mauk JL, Black PM. 2012. Geochemical and isotopic development of the Coromandel Volcanic Zone, northern New Zealand, since 18 Ma. Journal of Volcanology and Geothermal Research. 219-220:15-32.

Briggs RM. 1986a. Petrology and geochemistry of Maungatautari, a medium-k andesite-dacite volcano. New Zealand Journal of Geology and Geophysics. 29(3):273-289.

Briggs RM. 1986b. Volcanic rocks of the Waikato region, western North Island, and some possible petrologic and tectonic constraints on their origin. Late Cenozoic volcanism in New Zealand Royal Society of New Zealand bulletin. 23:76-91.

Briggs RM, Goles GG. 1984. Petrological and trace element geochemical features of the Okete Volcanics, western North Island, New Zealand. Contributions to Mineralogy and Petrology. 86(1):77-88.

Briggs RM, Goles GG, Maas R. 2013. Karioi volcano, western North Island, New Zealand: a behind arc polygenetic intraplate-convergent margin volcanic complex. Poster presented at the IAVCEI Scientific Assembly; Kagoshima, Japan.

Briggs RM, Itaya T, Lowe DJ, Keane AJ. 1989. Ages of the Pliocene-Pleistocene Alexandra and Ngatutura Volcanics, western North Island, New Zealand, and some geological implications. New Zealand Journal of Geology and Geophysics. 32(4):417-427.

Briggs RM, McDonough WF. 1990. Contemporaneous convergent margin and intraplate magmatism, North Island, New Zealand. Journal of Petrology. 31(4):813-851.

Cole J, Teoh L. 1975. Petrography, mineralogy, and chemistry of Pureora andesite volcano, North Island, New Zealand. New Zealand Journal of Geology and Geophysics. 18(2):259-272.

Cole JW. 1978. Distribution, petrography, and chemistry of Kiwitahi and Maungatautari volcanics, North Island, New Zealand. New Zealand Journal of Geology and Geophysics. 21(2):143-153. 
Eggins SM. 2003. Laser ablation ICPMS analysis of geological materials prepared as lithium borate glasses. Geostandards and Geoanalytical Research. 27(2):147162.

Froude D, Cole J. 1985. Petrography, mineralogy and chemistry of Titiraupenga volcano, North Island, New Zealand. New Zealand Journal of Geology and Geophysics. 28(3):487-496.

Gill R. 2010. Igneous rocks and processes: a practical guide. Chichester, West Sussex, UK: Wiley-Blackwell.

Hayward BW, Black PM, Smith IEM, Ballance PF, Itaya T, Doi M, Takagi M, Bergman S, Adams CJ, Herzer RH et al. 2001. K-Ar ages of early Miocene arctype volcanoes in northern New Zealand. New Zealand Journal of Geology and Geophysics. 44(2):285-311.

Healy J, Schofield J, Thompson B, compilers. 1964. Sheet 5 Rotorua. Geological Map of New Zealand 1:250 000. Wellington, New Zealand: Department of Scientific and Industrial Research.

Huang Y, Hawkesworth C, Smith I, van Calsteren P, Black P. 2000. Geochemistry of late cenozoic basaltic volcanism in Northland and Coromandel, New Zealand: implications for mantle enrichment processes. Chemical Geology. 164(3):219238.

Ito E, White WM, Göpel C. 1987. The O, Sr, $\mathrm{Nd}$ and Pb isotope geochemistry of MORB. Chemical Geology. 62(3-4):157-176.

Jochum KP, Nohl U, Herwig K, Lammel E, Stoll B, Hofmann AW. 2005. GeoReM: A new geochemical database for reference materials and isotopic standards. Geostandards and Geoanalytical Research. 29(3):333-338.

Kear D. 1964. Volcanic alignments north and west of New Zealand's Central Volcanic Region. New Zealand Journal of Geology and Geophysics. 7(1):24-44.

Kelemen PB, Hanghøj K, Greene AR. 2013, Chapter 4.21 - One view of the geochemistry of subduction-related magmatic arcs, with an emphasis on primitive andesite and lower crust. In: Turekian KK, editor. Treatise on Geochemistry (Second Edition). Oxford: Elsevier; p. 749-806.

Kuschel E, Smith IEM. 1992. Rare earth mobility in young arc-type volcanic rocks from northern New Zealand. Geochimica et Cosmochimica Acta. 56(11):39513955. 
Leonard GS, Begg JG, Wilson CJN, compilers. 2010. Geology of the Rotorua area. Geological map 5 1:250 000. Lower Hutt, New Zealand: GNS Science.

Neal CR, Taylor LA. 1989. A negative Ce anomaly in a peridotite xenolith: evidence for crustal recycling into the mantle or mantle metasomatism? Geochimica et Cosmochimica Acta. 53(5):1035-1040.

Olissoff ES. 1981. Quaternary stratigraphy and ignimbrites of the Karapiro-Arapuni region [MSc thesis]. Hamilton, New Zealand: University of Waikato.

Olson OP. 1950. Geology of the Maungatautari area, south-east of Cambridge [MSc thesis]. Auckland, New Zealand: University of Auckland.

Pin C, Gannoun A, Dupont A. 2014. Rapid, simultaneous separation of Sr, Pb, and $\mathrm{Nd}$ by extraction chromatography prior to isotope ratios determination by TIMS and MC-ICP-MS. Journal of Analytical Atomic Spectrometry. 29(10):1858-1870.

Prentice ML. 2017. Volcanic geology of Maungatautari: An andesitic-dacitic composite cone, Central Waikato, New Zealand [MSc thesis]. Hamilton, New Zealand: University of Waikato.

Price R, Gamble JA, Smith IE, Maas R, Waight T, Stewart RB, Woodhead J. 2012. The anatomy of an andesite volcano: a time-stratigraphic study of andesite petrogenesis and crustal evolution at Ruapehu Volcano, New Zealand. Journal of Petrology. 53(10):2139-2189.

Price R, Mortimer N, Smith I, Maas R. 2015. Whole-rock geochemical reference data for Torlesse and Waipapa terranes, North Island, New Zealand. New Zealand Journal of Geology and Geophysics. 58(3):213-228.

Price RC, Gray CM, Wilson RE, Frey FA, Taylor SR. 1991. The effects of weathering on rare-earth element, $\mathrm{Y}$ and $\mathrm{Ba}$ abundances in Tertiary basalts from southeastern Australia. Chemical Geology. 93(3):245-265.

Price RC, Smith IE, Stewart RB, Gamble JA, Gruender K, Maas R. 2016. High-K andesite petrogenesis and crustal evolution: Evidence from mafic and ultramafic xenoliths, Egmont Volcano (Mt. Taranaki) and comparisons with Ruapehu Volcano, North Island, New Zealand. Geochimica et Cosmochimica Acta. 185:328-357.

Price RC, Stewart RB, Woodhead JD, Smith IEM. 1999. Petrogenesis of high-K arc magmas: Evidence from Egmont Volcano, North Island, New Zealand. Journal of Petrology. 40(1):167-197. 
Robertson D. 1983. Paleomagnetism and geochronology of volcanics in the northern North Island [PhD thesis]. Auckland, New Zealand: University of Auckland. Roden MF, Frey FA, Clague DA. 1984. Geochemistry of tholeiitic and alkalic lavas from the Koolau Range, Oahu, Hawaii: Implications for Hawaiian volcanism. Earth and Planetary Science Letters. 69(1):141-158.

Simmons SF, White NC, John DA. 2005. Geological characteristics of epithermal precious and base metal deposits. Economic Geology. 29:485-522.

Sun S, McDonough W. 1989. Chemical and isotopic systematics of oceanic basalts: implications for mantle composition and processes. Geological Society, London, Special Publications. 42(1):313-345.

Taylor S, McLennan S. 1985. The continental crust: Its evolution and composition. Blackwell, London.

Waikato Regional Council. n.d. Data Catalogue [accessed May 2017]. https://www.waikatoregion.govt.nz/services/data-catalogue/.

Wilson CJN, Rowland JV. 2016. The volcanic, magmatic and tectonic setting of the Taupo Volcanic Zone, New Zealand, reviewed from a geothermal perspective. Geothermics. 59, Part B:168-187.

Winchester JA, Floyd PA. 1977. Geochemical discrimination of different magma series and their differentiation products using immobile elements. Chemical Geology. $20: 325-343$.

Winter JD. 2014. Principles of igneous and metamorphic petrology. 2nd ed. Harlow, UK: Pearson Education. 


\section{Fig. Captions:}

Fig. 1. Locality map of the western Waikato Region.

Fig. 2. Geologic map for Maungatautari and its surrounds.

Fig. 3. Quarry \#34. A) Stratigraphic architecture and stratigraphic log. B) Outcrop photo.

Fig. 4. Summit quarry. A) Stratigraphic architecture and stratigraphic log. B) Outcrop photo.

Fig. 5. A) Facies A, B and C in outcrop at quarry \#34 where the massive lapilli tuff of facies A contrasts with the laminated-bedded crystal and lithic-rich coarse tuff and veryfine lapilli of facies B. The thin tuff beds of facies $\mathrm{C}$ form two thin and laterally continuous bands across the outcrop. B) Facies A within unit SQ2 at the summit quarry. C) Facies D in outcrop at the summit quarry displaying red-coloured, matrixsupported, poorly sorted, non-welded massive lapilli-block tuff. D) Facies E of unit SQ3 within the summit quarry showing reverse grading of blocks and fines-rich basal layer marked near the base of the photo by the top of the scraper which is used for scale.

Fig. 6. Geomorphology of the Maungatautari rock avalanche. A) View eastward of the area affected by a rock avalanche from the top of the breakaway scarp. The steep-sided walls are covered in native bush and form a characteristic horse-shoe pattern surrounding predominantly flat, poor-draining land. Arrows point to large hummocks which lie to the east from the edge of the tree line. B) North-south and west-east GIS cross-sectional profiles outlined in Error! Reference source not found.. C) Large proximal hummock consisting of medium-sized, unsorted and unstratified angular to sub-angular blocks and matrix mantled by post-collapse tephra deposits.

Fig. 7. Normalised trace element data for StHs and ML3B-G standards measured by LA-ICP-MS. Of the 25 elements measured, 12 are within $\mathrm{ca} \pm 5 \%$ of the recommended reference values of Jochum et al. (2005) with another 10 within ca $\pm 10 \%$.

Fig. 8. Selected Harker diagrams for Maungatautari and Kairangi lavas.

Fig. 9. Mg\# for Maungatautari and Kairangi lavas. 
Fig. 10. Primordial mantle normalised multi-element diagram for representative Maungatautari and Kairangi lavas. Normalisation factors after Taylor and McLennan (1985).

Fig. 11. NMORB normalised REE diagram for representative Maungatautari and Kairangi lavas. Normalisation factors after Sun and McDonough (1989).

Fig. 12. Radiogenic Sr and Nd isotopic compositions of representative Maungatautari and Kairangi lavas compared with Ruapehu andesites and basalts (Price et al. 2012), Coromandel Volcanic Zone (Huang et al. 2000), Mt Taranaki (Price et al. 1999), Alexandra Volcanics (Briggs and McDonough 1990) and the Okete Volcanic group (Briggs and Goles 1984). Data for the regional basement terrane (Price et al. 2015) and MORB lavas (Ito et al. 1987) are also included for reference.

Fig. 13. Primordial mantle normalised multi-element diagram for averaged geochemical data from the Coromandel Volcanic Zone (Booden et al. 2012), Kiwitahi (Booden et al. 2010), Ruapehu (Price et al. 2012), Alexandra (Briggs and Goles 1984; Briggs 1986b) and Taranaki (Price et al. 1999) volcanic centres and the Okete intraplate volcanics of the western North Island (Briggs and McDonough 1990). Normalisation factors after Taylor and McLennan (1985).

Fig. 14. Schematic map showing the estimated position of the Colville volcanic arc at c. $2 \mathrm{Ma}$ and its propagation through the western North Island to include Maungatautari. Active volcanic centres are shown by red triangles. The continuation of the arc to include the western Taranaki Graben Volcanoes (dashed line) remains speculative. 
Table 1. Modal analyses of selected Maungatautari lavas based on a minimum of 350 counts per slide. OB, olivine basalt; PA, pyroxene andesite; LA, labradorite andesite; HA, hornblende andesite; HD, hornblende dacite.

\begin{tabular}{|c|c|c|c|c|c|c|c|c|c|c|c|}
\hline Sample No. & KSC001 & GF006 & MSE019 & MRd022 & ORE039 & ORE040 & HF044 & MSE054 & MSE056 & MSE057 & MSE062 \\
\hline Location & $\begin{array}{c}\text { Kairangi } \\
\text { basalt } \\
\text { cone }\end{array}$ & $\begin{array}{l}\text { Garland } \\
\text { lava flow }\end{array}$ & Little Rock & $\begin{array}{l}\text { Hillside, Sth } \\
\text { Mangaoha } \\
\text { Stream }\end{array}$ & $\begin{array}{l}\text { Oreipunga } \\
\text { Cone }\end{array}$ & $\begin{array}{l}\text { Gully } \\
\text { between } \\
\text { Oreipunga } \\
\text { cone and } \\
\text { fence }\end{array}$ & $\begin{array}{l}\text { Hicks farm } \\
\text { lava flow }\end{array}$ & Quarry 45 & $\begin{array}{l}\text { Pukeatua } \\
\text { peak }\end{array}$ & $\begin{array}{l}\text { Rocky } \\
\text { outcrop }\end{array}$ & Trig \\
\hline $\begin{array}{l}\text { Petrographic } \\
\text { classification }\end{array}$ & OB & PA & HD & LA & HD & HA & HA & PA & HD & HD & HA \\
\hline Plagioclase (\%) & 2 & 28 & 28 & 37 & 26 & 34 & 28 & 33 & 18 & 20 & 27 \\
\hline Olivine (\%) & 17 & - & - & - & - & - & - & - & - & - & - \\
\hline Pyroxene (total \%) & 3 & 18 & 13 & 13 & 1 & 13 & 16 & 18 & 14 & 1 & 1 \\
\hline Hornblende (\%) & - & - & 2 & - & 15 & 3 & 6 & 1 & 5 & 15 & 19 \\
\hline Fe-Ti Oxides (\%) & - & 3 & 1 & 2 & 1 & 2 & 1 & 1 & 2 & 2 & 1 \\
\hline Quartz (\%) & - & - & - & - & - & - & - & - & 1 & - & - \\
\hline Total crystals (\%) & 22 & 49 & 44 & 52 & 43 & 52 & 51 & 53 & 40 & 38 & 48 \\
\hline Groundmass (\%) & 78 & 51 & 56 & 48 & 57 & 48 & 49 & 47 & 60 & 62 & 52 \\
\hline Total (\%) & 100 & 100 & 100 & 100 & 100 & 100 & 100 & 100 & 100 & 100 & 100 \\
\hline
\end{tabular}


Table 2. Representative whole rock geochemical analyses by XRF and LA-ICP-MS for Maungatautari lavas.

\begin{tabular}{|c|c|c|c|c|c|c|c|c|c|}
\hline $\begin{array}{l}\text { Sample } \\
\text { Name }\end{array}$ & KSC001 & GF006 & MSE019 & MRd020 & ORE039B & ORE040 & MSE054 & MSE056 & MSE057 \\
\hline \multicolumn{10}{|c|}{ Major elements (XRF, wt.\%) } \\
\hline \multicolumn{10}{|c|}{ (Normalized to $100 \%$ on LOI, volatile free; $\mathrm{LOI}$ and Total are original values; all Fe expressed as $\mathrm{Fe}_{2} \mathrm{O}_{3}$ ) } \\
\hline $\mathrm{SiO}_{2}$ & 49.65 & 60.68 & 63.28 & 61.38 & 63.68 & 58.75 & 58.83 & 63.88 & 66.45 \\
\hline $\mathrm{Al}_{2} \mathrm{O}_{3}$ & 14.61 & 16.54 & 17.00 & 17.24 & 18.15 & 17.52 & 17.57 & 18.05 & 16.85 \\
\hline $\mathrm{TiO}_{2}$ & 1.50 & 0.67 & 0.48 & 0.65 & 0.59 & 0.70 & 0.76 & 0.52 & 0.52 \\
\hline $\mathrm{MnO}$ & 0.17 & 0.11 & 0.11 & 0.11 & 0.15 & 0.13 & 0.11 & 0.09 & 0.05 \\
\hline $\mathrm{Fe}_{2} \mathrm{O}_{3}$ & 10.88 & 7.22 & 5.88 & 5.89 & 6.59 & 7.92 & 7.15 & 6.01 & 5.13 \\
\hline $\mathrm{Na}_{2} \mathrm{O}$ & 2.91 & 3.30 & 3.65 & 3.67 & 3.42 & 3.19 & 3.27 & 3.23 & 3.42 \\
\hline MgO & 8.55 & 3.32 & 2.04 & 2.53 & 0.67 & 3.48 & 3.34 & 1.97 & 1.10 \\
\hline $\mathrm{K}_{2} \mathrm{O}$ & 1.36 & 2.04 & 2.12 & 1.97 & 2.42 & 1.96 & 1.95 & 2.37 & 2.77 \\
\hline $\mathrm{CaO}$ & 10.00 & 5.90 & 5.20 & 5.6 & 4.09 & 6.11 & 6.79 & 3.69 & 3.54 \\
\hline $\mathrm{P}_{2} \mathrm{O}_{5}$ & 0.36 & 0.22 & 0.22 & 0.23 & 0.26 & 0.22 & 0.24 & 0.19 & 0.16 \\
\hline LOI (\%) & 0.62 & 1.72 & 1.72 & 1.31 & 2.84 & 2.03 & 1.73 & 4.05 & 3.75 \\
\hline Total (\%) & 99.40 & 100.06 & 100.43 & 100.78 & 100.82 & 100.51 & 100.85 & 100.03 & 99.88 \\
\hline \multicolumn{10}{|c|}{ Trace elements (LA-ICP-MS, ppm) } \\
\hline Sc & 25.20 & 13.86 & 10.72 & 11.6 & 9.97 & 16.30 & 17.60 & 11.90 & 9.39 \\
\hline V & 244.40 & 171.90 & 134.95 & 151.4 & 151.60 & 205.60 & 199.20 & 143.40 & 127.90 \\
\hline $\mathrm{Rb}$ & 21.10 & 52.90 & 52.95 & 48.4 & 63.00 & 48.10 & 48.70 & 58.20 & 72.20 \\
\hline $\mathrm{Sr}$ & 421.00 & 346.40 & 365.80 & 353.9 & 347.10 & 304.60 & 398.60 & 263.50 & 296.90 \\
\hline Y & 17.55 & 27.40 & 15.20 & 15.9 & 19.00 & 74.60 & 16.60 & 16.11 & 16.30 \\
\hline $\mathrm{Zr}$ & 113.60 & 118.20 & 121.30 & 118.1 & 141.90 & 107.40 & 113.20 & 123.90 & 146.70 \\
\hline $\mathrm{Nb}$ & 18.90 & 7.41 & 7.92 & 7.37 & 8.78 & 6.84 & 5.74 & 7.51 & 9.35 \\
\hline Cs & 0.46 & 1.87 & 1.26 & 0.79 & 1.09 & 1.63 & 1.15 & 1.71 & 1.83 \\
\hline $\mathrm{Ba}$ & 320.20 & 512.00 & 604.50 & 519 & 600.00 & 488.00 & 495.00 & 615.00 & 690.00 \\
\hline La & 23.00 & 41.90 & 23.75 & 22.9 & 29.00 & 34.10 & 20.70 & 27.70 & 32.00 \\
\hline $\mathrm{Ce}$ & 40.90 & 45.30 & 41.30 & 43.7 & 48.30 & 37.60 & 40.90 & 42.60 & 43.40 \\
\hline $\mathrm{Pr}$ & 4.93 & 8.56 & 5.26 & 4.44 & 6.43 & 9.73 & 5.74 & 6.22 & 6.64 \\
\hline $\mathrm{Nd}$ & 25.70 & 38.00 & 25.70 & 24.3 & 28.50 & 42.10 & 23.40 & 29.40 & 27.50 \\
\hline Sm & 4.00 & 6.40 & 4.70 & 2.86 & 4.96 & 10.20 & 3.83 & 4.50 & 3.81 \\
\hline $\mathrm{Eu}$ & 1.19 & 1.99 & 1.12 & 1.16 & 1.07 & 3.07 & 0.83 & 1.10 & 0.70 \\
\hline $\mathrm{Gd}$ & 3.54 & 6.20 & 2.97 & 3.4 & 3.47 & 12.30 & 2.89 & 3.30 & 2.94 \\
\hline Dy & 2.90 & 4.94 & 2.61 & 2.68 & 3.32 & 12.70 & 2.96 & 2.77 & 1.92 \\
\hline Ho & 0.71 & 0.92 & 0.48 & 0.47 & 0.76 & 2.44 & 0.66 & 0.47 & 0.47 \\
\hline $\mathrm{Er}$ & 1.94 & 2.88 & 1.57 & 1.05 & 2.00 & 6.40 & 2.01 & 1.53 & 1.71 \\
\hline $\mathrm{Yb}$ & 2.03 & 2.93 & 1.54 & 2.12 & 2.26 & 6.40 & 1.37 & 1.37 & 1.74 \\
\hline Lu & 0.19 & 0.42 & 0.19 & 0.33 & 0.35 & 1.12 & 0.21 & 0.30 & 0.33 \\
\hline $\mathrm{Pb}$ & 1.92 & 3.29 & 3.84 & 2.45 & 6.00 & 4.32 & 3.77 & 4.05 & 4.77 \\
\hline Th & 3.36 & 6.94 & 7.35 & 6.92 & 9.14 & 5.99 & 6.22 & 8.31 & 10.87 \\
\hline U & 0.98 & 1.42 & 1.70 & 1.59 & 2.03 & 1.54 & 1.72 & 1.63 & 2.35 \\
\hline${ }^{87} \mathrm{Sr} /{ }^{86} \mathrm{Sr}$ & 0.703850 & 0.704478 & & 0.704555 & 0.704784 & 0.704645 & & & \\
\hline${ }^{143} \mathrm{Nd} /{ }^{144} \mathrm{Nd}$ & 0.512849 & 0.512810 & & 0.512807 & 0.512771 & 0.512775 & & & \\
\hline
\end{tabular}




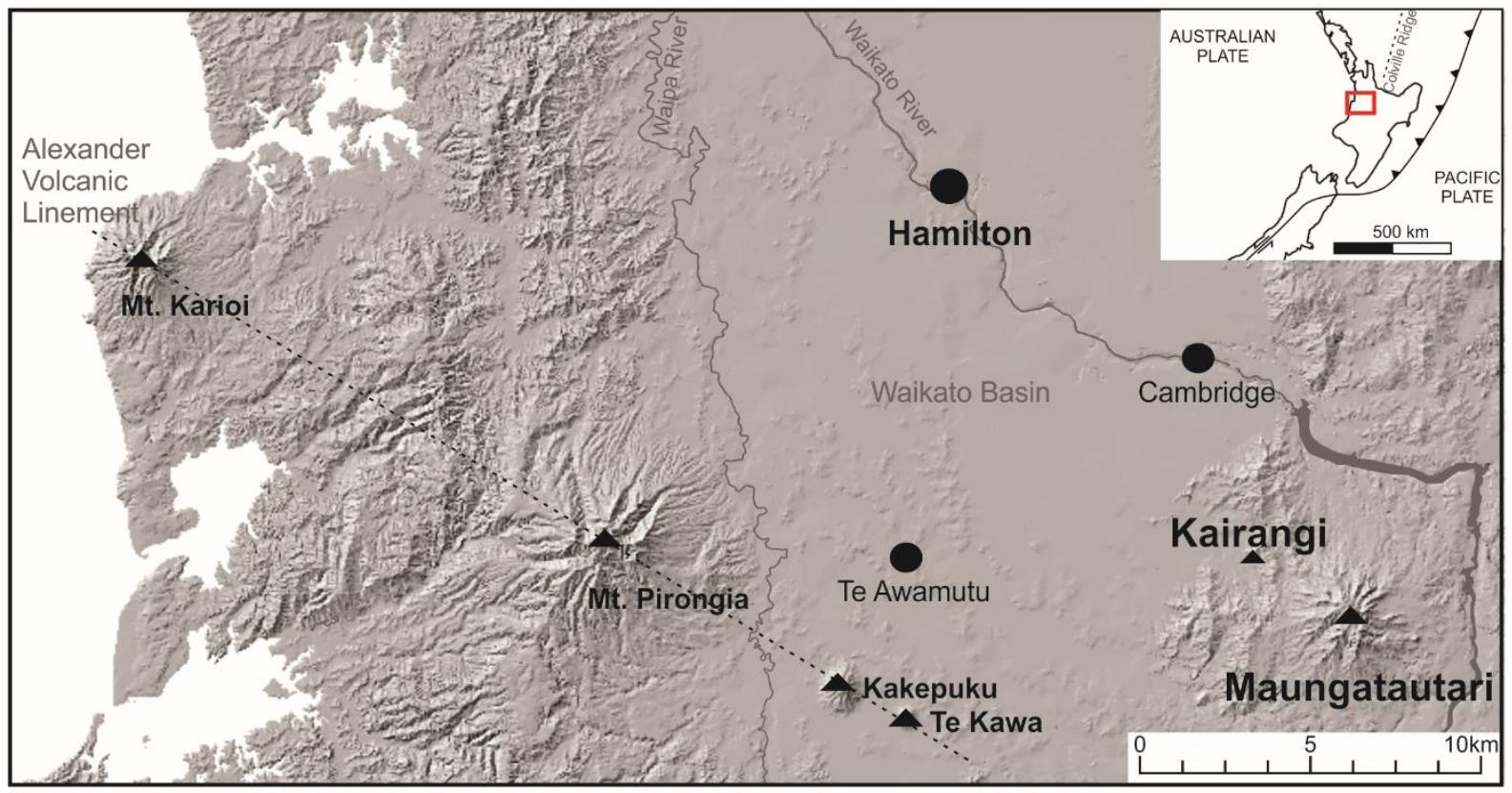

Figure 1. Locality map of the western Waikato Region. 


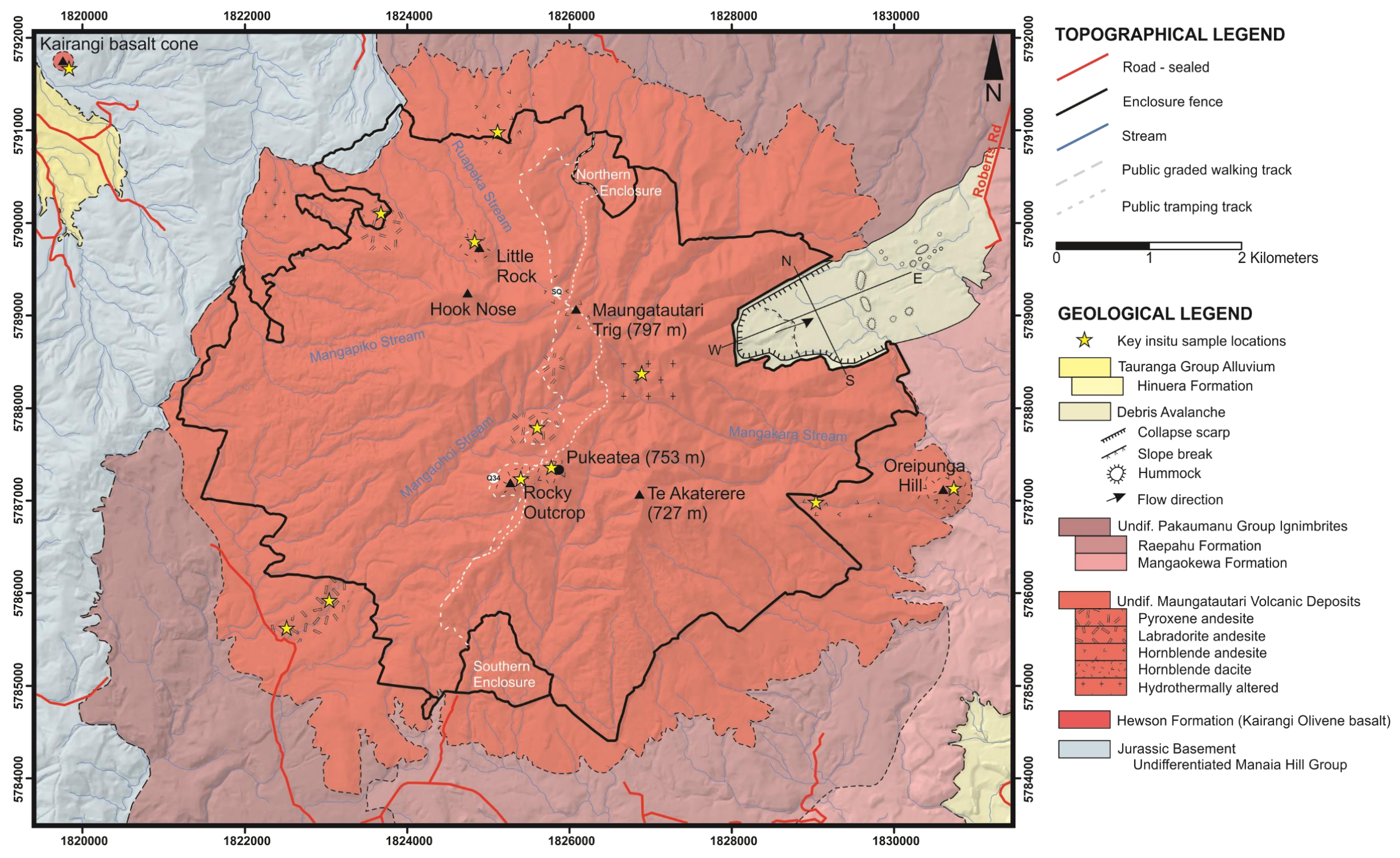

Figure 2. Geologic map for Maungatautari and its surrounds. 
Table 1. Modal analyses of selected Maungatautari lavas based on a minimum of 350 counts per slide. OB, olivine basalt; PA, pyroxene andesite; LA, labradorite andesite; HA, hornblende andesite; HD, hornblende dacite.

\begin{tabular}{|c|c|c|c|c|c|c|c|c|c|c|c|}
\hline Sample No. & KSC001 & GF006 & MSE019 & MRd022 & ORE039 & ORE040 & HF044 & MSE054 & MSE056 & MSE057 & MSE062 \\
\hline Location & $\begin{array}{c}\text { Kairangi } \\
\text { basalt } \\
\text { cone }\end{array}$ & $\begin{array}{l}\text { Garland } \\
\text { lava flow }\end{array}$ & Little Rock & $\begin{array}{l}\text { Hillside, Sth } \\
\text { Mangaoha } \\
\text { Stream }\end{array}$ & $\begin{array}{l}\text { Oreipunga } \\
\text { Cone }\end{array}$ & $\begin{array}{l}\text { Gully } \\
\text { between } \\
\text { Oreipunga } \\
\text { cone and } \\
\text { fence }\end{array}$ & $\begin{array}{l}\text { Hicks farm } \\
\text { lava flow }\end{array}$ & Quarry 45 & $\begin{array}{c}\text { Pukeatua } \\
\text { peak }\end{array}$ & $\begin{array}{l}\text { Rocky } \\
\text { outcrop }\end{array}$ & Trig \\
\hline $\begin{array}{l}\text { Petrographic } \\
\text { classification }\end{array}$ & OB & PA & HD & LA & HD & HA & HA & PA & HD & HD & HA \\
\hline Plagioclase (\%) & 2 & 28 & 28 & 37 & 26 & 34 & 28 & 33 & 18 & 20 & 27 \\
\hline Olivine (\%) & 17 & - & - & - & - & - & - & - & - & - & - \\
\hline Pyroxene (total \%) & 3 & 18 & 13 & 13 & 1 & 13 & 16 & 18 & 14 & 1 & 1 \\
\hline Hornblende (\%) & - & - & 2 & - & 15 & 3 & 6 & 1 & 5 & 15 & 19 \\
\hline Fe-Ti Oxides (\%) & - & 3 & 1 & 2 & 1 & 2 & 1 & 1 & 2 & 2 & 1 \\
\hline Quartz (\%) & - & - & - & - & - & - & - & - & 1 & - & - \\
\hline Total crystals (\%) & 22 & 49 & 44 & 52 & 43 & 52 & 51 & 53 & 40 & 38 & 48 \\
\hline Groundmass (\%) & 78 & 51 & 56 & 48 & 57 & 48 & 49 & 47 & 60 & 62 & 52 \\
\hline Total (\%) & 100 & 100 & 100 & 100 & 100 & 100 & 100 & 100 & 100 & 100 & 100 \\
\hline
\end{tabular}


A)

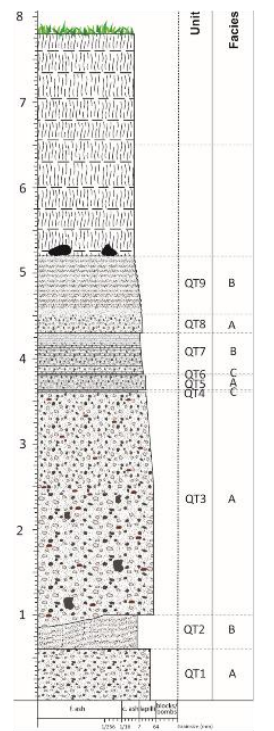

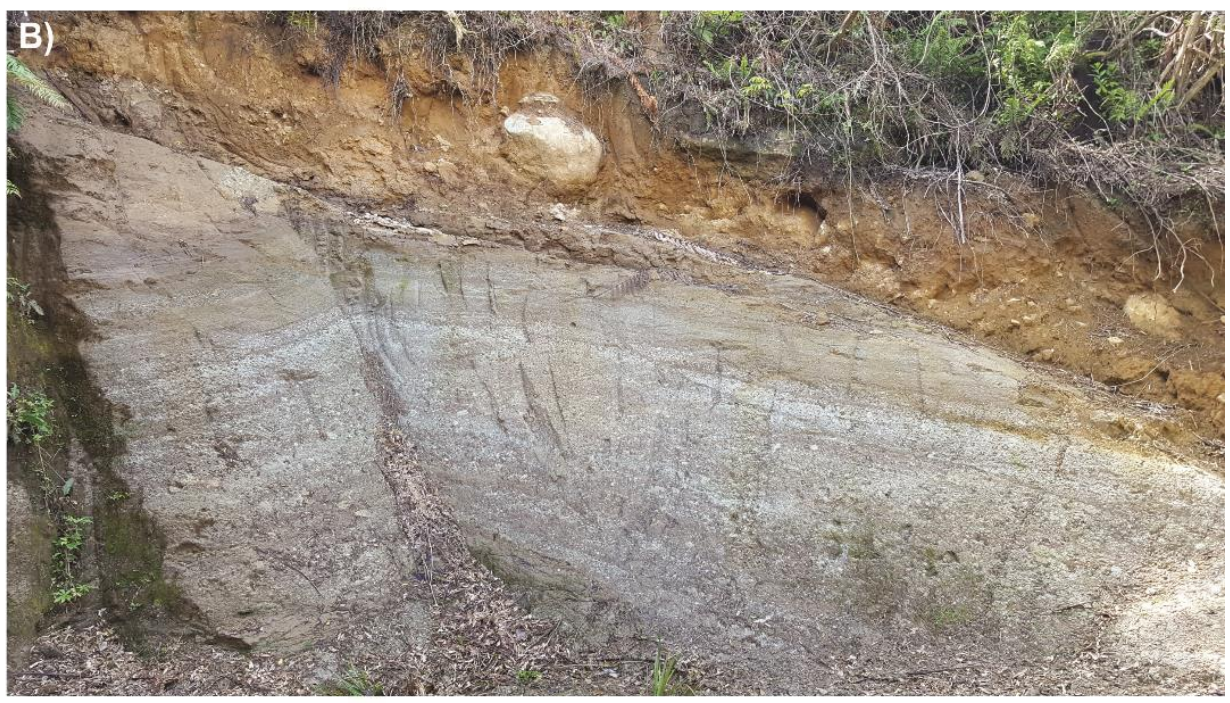

Figure 3. Quarry \#34. A) Stratigraphic architecture and stratigraphic log. B) Outcrop photo.
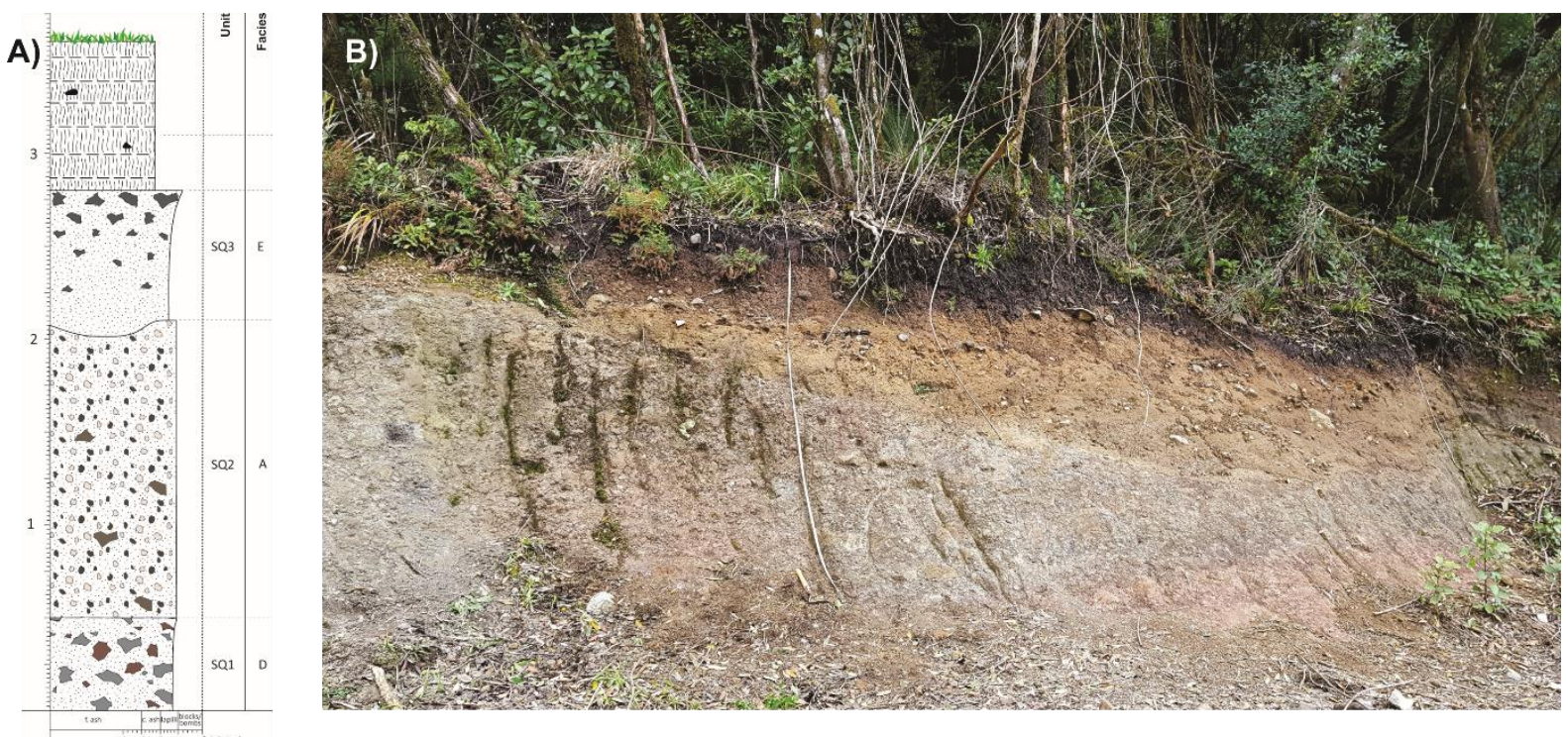

Figure 4. Summit quarry. A) Stratigraphic architecture and stratigraphic log. B) Outcrop photo. 

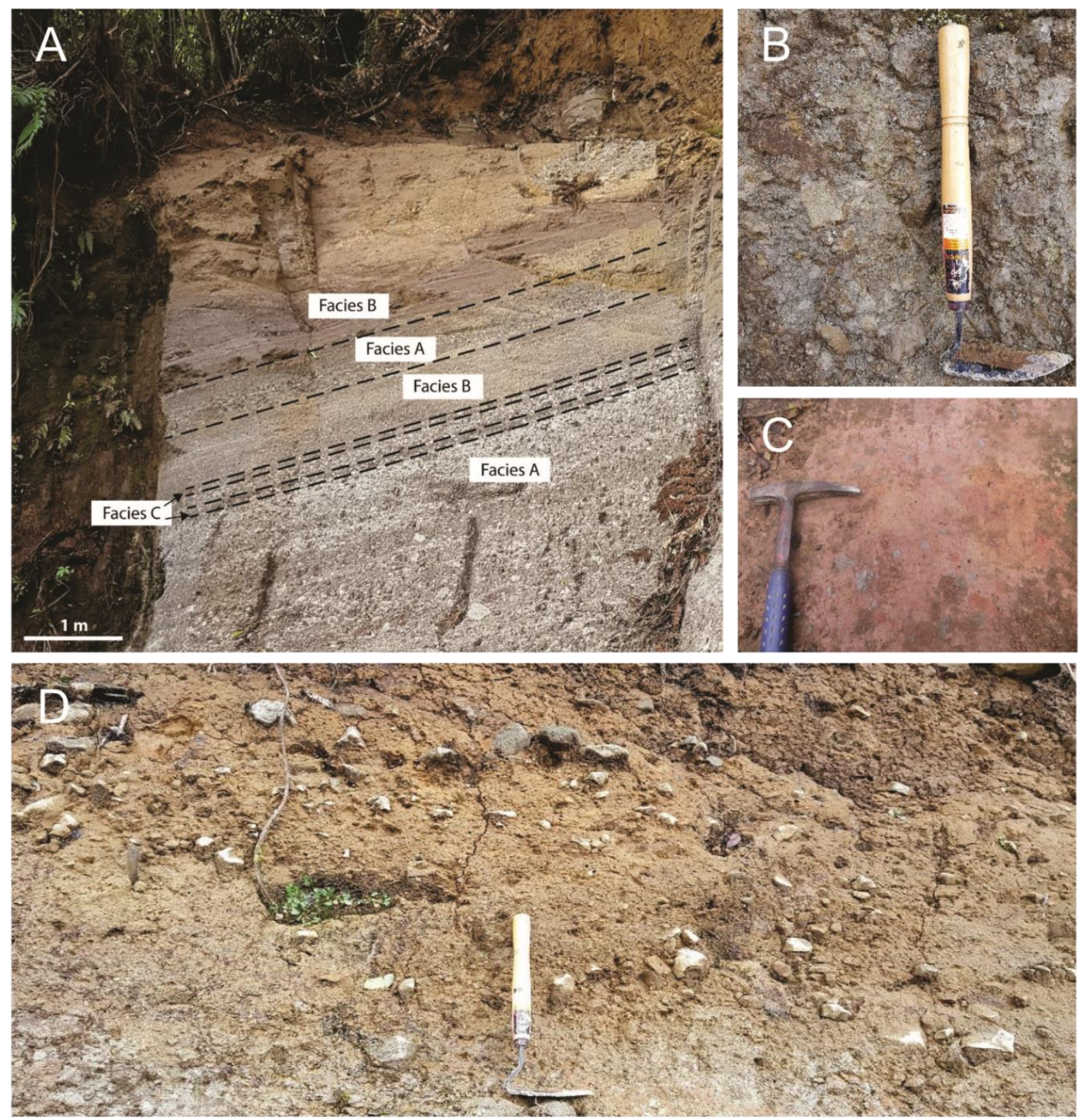

Figure 5. A) Facies A, B and C in outcrop at quarry \#34 where the massive lapilli tuff of facies A contrasts with the laminated-bedded crystal and lithic-rich coarse tuff and very-fine lapilli of facies B. The thin tuff beds of facies $\mathrm{C}$ form two thin and laterally continuous bands across the outcrop. B) Facies A within unit SQ2 at the summit quarry. C) Facies D in outcrop at the summit quarry displaying red-coloured, matrix-supported, poorly sorted, non-welded massive lapilli-block tuff. D) Facies E of unit SQ3 within the summit quarry showing reverse grading of blocks and fines-rich basal layer marked near the base of the photo by the top of the scraper which is used for scale. 

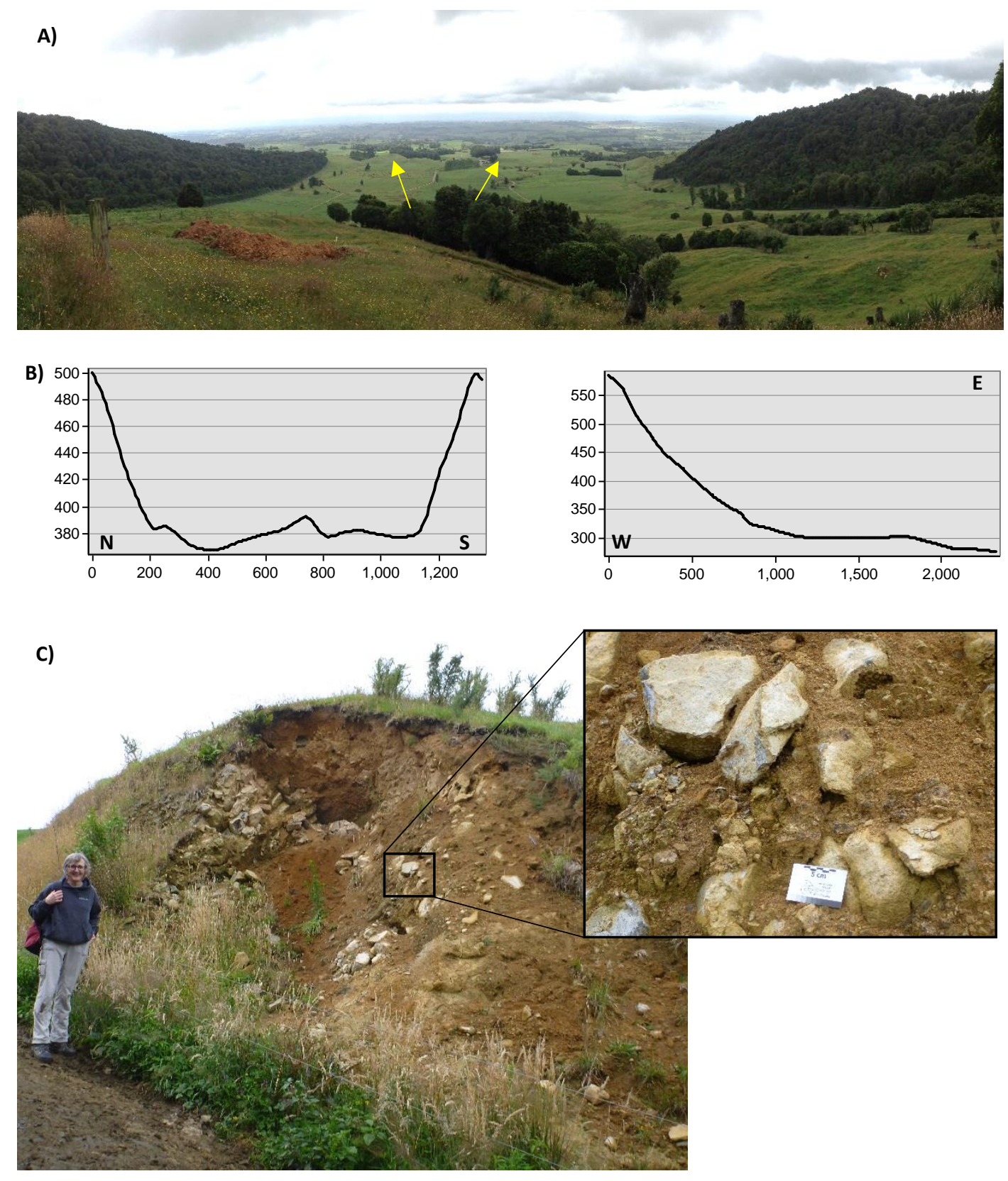

Figure 6. Geomorphology of the Maungatautari rock avalanche. A) View eastward of the area affected by a rock avalanche from the top of the breakaway scarp. The steep-sided walls are covered in native bush and form a characteristic horse-shoe pattern surrounding predominantly flat, poor-draining land. Arrows point to large hummocks which lie to the east from the edge of the tree line. B) North-south and west-east GIS cross-sectional profiles outlined in Fig. 2. C) Large proximal hummock consisting of mid-sized, unsorted and unstratified angular to subangular blocks and matrix mantled by post-collapse tephra deposits. 


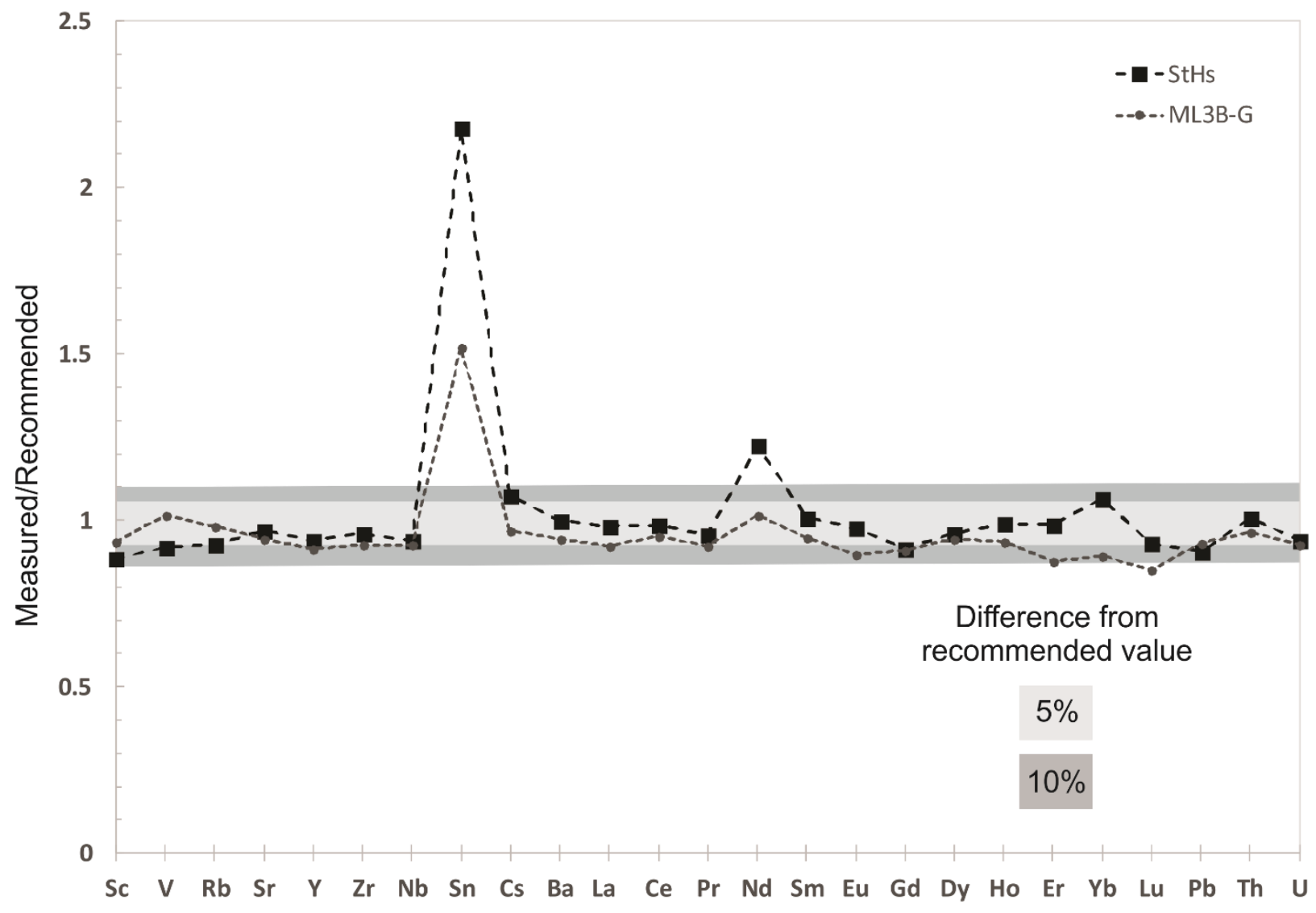

Figure 7. Normalised trace element data for StHs and ML3B-G standards measured by LA-ICPMS. Of the 25 elements measured, 12 are within ca $\pm 5 \%$ of the recommended reference values of Jochum et al. (2005) with another 10 within ca $\pm 10 \%$. 
Table 2. Representative whole rock geochemical analyses by XRF and LA-ICP-MS for Maungatautari lavas

\begin{tabular}{|c|c|c|c|c|c|c|c|c|c|}
\hline $\begin{array}{l}\text { Sample } \\
\text { Name }\end{array}$ & KSC001 & GF006 & MSE019 & MRd020 & ORE039B & ORE040 & MSE054 & MSE056 & MSE057 \\
\hline \multicolumn{10}{|c|}{ Major elements (XRF, wt.\%) } \\
\hline \multicolumn{10}{|c|}{ (Normalized to $100 \%$ on $\mathrm{LOI}$, volatile free; $\mathrm{LOI}$ and Total are original values; all Fe expressed as $\mathrm{Fe}_{2} \mathrm{O}_{3}$ ) } \\
\hline $\mathrm{SiO}_{2}$ & 49.65 & 60.68 & 63.28 & 61.38 & 63.68 & 58.75 & 58.83 & 63.88 & 66.45 \\
\hline $\mathrm{Al}_{2} \mathrm{O}_{3}$ & 14.61 & 16.54 & 17.00 & 17.24 & 18.15 & 17.52 & 17.57 & 18.05 & 16.85 \\
\hline $\mathrm{TiO}_{2}$ & 1.50 & 0.67 & 0.48 & 0.65 & 0.59 & 0.70 & 0.76 & 0.52 & 0.52 \\
\hline $\mathrm{MnO}$ & 0.17 & 0.11 & 0.11 & 0.11 & 0.15 & 0.13 & 0.11 & 0.09 & 0.05 \\
\hline $\mathrm{Fe}_{2} \mathrm{O}_{3}$ & 10.88 & 7.22 & 5.88 & 5.89 & 6.59 & 7.92 & 7.15 & 6.01 & 5.13 \\
\hline $\mathrm{Na}_{2} \mathrm{O}$ & 2.91 & 3.30 & 3.65 & 3.67 & 3.42 & 3.19 & 3.27 & 3.23 & 3.42 \\
\hline $\mathrm{MgO}$ & 8.55 & 3.32 & 2.04 & 2.53 & 0.67 & 3.48 & 3.34 & 1.97 & 1.10 \\
\hline $\mathrm{K}_{2} \mathrm{O}$ & 1.36 & 2.04 & 2.12 & 1.97 & 2.42 & 1.96 & 1.95 & 2.37 & 2.77 \\
\hline $\mathrm{CaO}$ & 10.00 & 5.90 & 5.20 & 5.6 & 4.09 & 6.11 & 6.79 & 3.69 & 3.54 \\
\hline $\mathrm{P}_{2} \mathrm{O}_{5}$ & 0.36 & 0.22 & 0.22 & 0.23 & 0.26 & 0.22 & 0.24 & 0.19 & 0.16 \\
\hline LOI (\%) & 0.62 & 1.72 & 1.72 & 1.31 & 2.84 & 2.03 & 1.73 & 4.05 & 3.75 \\
\hline Total (\%) & 99.40 & 100.06 & 100.43 & 100.78 & 100.82 & 100.51 & 100.85 & 100.03 & 99.88 \\
\hline \multicolumn{10}{|c|}{ Trace elements (LA-ICP-MS, ppm) } \\
\hline Sc & 25.20 & 13.86 & 10.72 & 11.6 & 9.97 & 16.30 & 17.60 & 11.90 & 9.39 \\
\hline V & 244.40 & 171.90 & 134.95 & 151.4 & 151.60 & 205.60 & 199.20 & 143.40 & 127.90 \\
\hline $\mathrm{Rb}$ & 21.10 & 52.90 & 52.95 & 48.4 & 63.00 & 48.10 & 48.70 & 58.20 & 72.20 \\
\hline $\mathrm{Sr}$ & 421.00 & 346.40 & 365.80 & 353.9 & 347.10 & 304.60 & 398.60 & 263.50 & 296.90 \\
\hline Y & 17.55 & 27.40 & 15.20 & 15.9 & 19.00 & 74.60 & 16.60 & 16.11 & 16.30 \\
\hline $\mathrm{Zr}$ & 113.60 & 118.20 & 121.30 & 118.1 & 141.90 & 107.40 & 113.20 & 123.90 & 146.70 \\
\hline $\mathrm{Nb}$ & 18.90 & 7.41 & 7.92 & 7.37 & 8.78 & 6.84 & 5.74 & 7.51 & 9.35 \\
\hline Cs & 0.46 & 1.87 & 1.26 & 0.79 & 1.09 & 1.63 & 1.15 & 1.71 & 1.83 \\
\hline $\mathrm{Ba}$ & 320.20 & 512.00 & 604.50 & 519 & 600.00 & 488.00 & 495.00 & 615.00 & 690.00 \\
\hline La & 23.00 & 41.90 & 23.75 & 22.9 & 29.00 & 34.10 & 20.70 & 27.70 & 32.00 \\
\hline $\mathrm{Ce}$ & 40.90 & 45.30 & 41.30 & 43.7 & 48.30 & 37.60 & 40.90 & 42.60 & 43.40 \\
\hline $\operatorname{Pr}$ & 4.93 & 8.56 & 5.26 & 4.44 & 6.43 & 9.73 & 5.74 & 6.22 & 6.64 \\
\hline $\mathrm{Nd}$ & 25.70 & 38.00 & 25.70 & 24.3 & 28.50 & 42.10 & 23.40 & 29.40 & 27.50 \\
\hline Sm & 4.00 & 6.40 & 4.70 & 2.86 & 4.96 & 10.20 & 3.83 & 4.50 & 3.81 \\
\hline $\mathrm{Eu}$ & 1.19 & 1.99 & 1.12 & 1.16 & 1.07 & 3.07 & 0.83 & 1.10 & 0.70 \\
\hline $\mathrm{Gd}$ & 3.54 & 6.20 & 2.97 & 3.4 & 3.47 & 12.30 & 2.89 & 3.30 & 2.94 \\
\hline Dy & 2.90 & 4.94 & 2.61 & 2.68 & 3.32 & 12.70 & 2.96 & 2.77 & 1.92 \\
\hline Ho & 0.71 & 0.92 & 0.48 & 0.47 & 0.76 & 2.44 & 0.66 & 0.47 & 0.47 \\
\hline $\mathrm{Er}$ & 1.94 & 2.88 & 1.57 & 1.05 & 2.00 & 6.40 & 2.01 & 1.53 & 1.71 \\
\hline $\mathrm{Yb}$ & 2.03 & 2.93 & 1.54 & 2.12 & 2.26 & 6.40 & 1.37 & 1.37 & 1.74 \\
\hline Lu & 0.19 & 0.42 & 0.19 & 0.33 & 0.35 & 1.12 & 0.21 & 0.30 & 0.33 \\
\hline $\mathrm{Pb}$ & 1.92 & 3.29 & 3.84 & 2.45 & 6.00 & 4.32 & 3.77 & 4.05 & 4.77 \\
\hline Th & 3.36 & 6.94 & 7.35 & 6.92 & 9.14 & 5.99 & 6.22 & 8.31 & 10.87 \\
\hline U & 0.98 & 1.42 & 1.70 & 1.59 & 2.03 & 1.54 & 1.72 & 1.63 & 2.35 \\
\hline${ }^{87} \mathrm{Sr} /{ }^{86} \mathrm{Sr}$ & 0.703850 & 0.704478 & & 0.704555 & 0.704784 & 0.704645 & & & \\
\hline${ }^{143} \mathrm{Nd} /{ }^{144} \mathrm{Nd}$ & 0.512849 & 0.512810 & & 0.512807 & 0.512771 & 0.512775 & & & \\
\hline
\end{tabular}



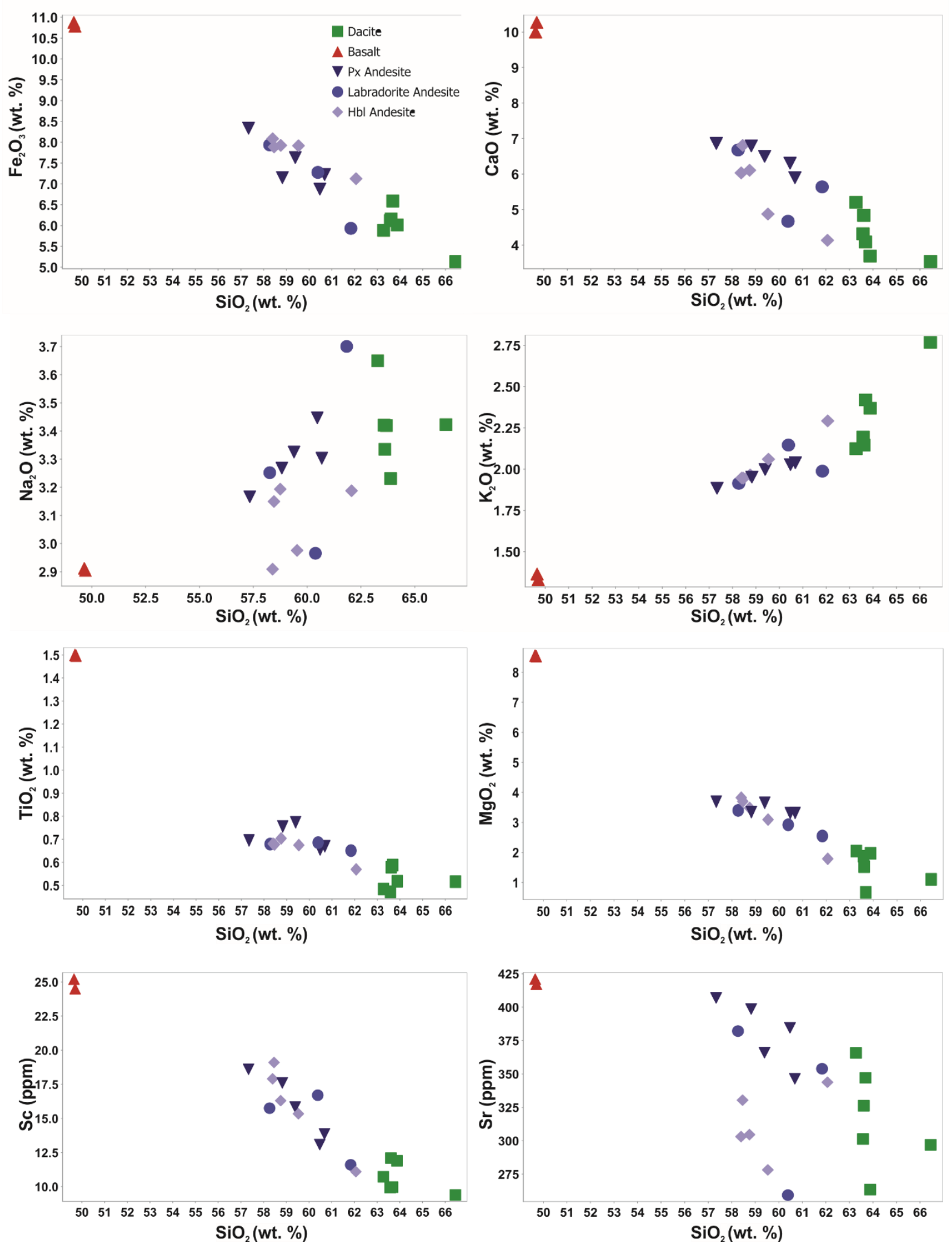

Figure 8. Selected Harker diagrams for Maungatautari and Kairangi lavas. 


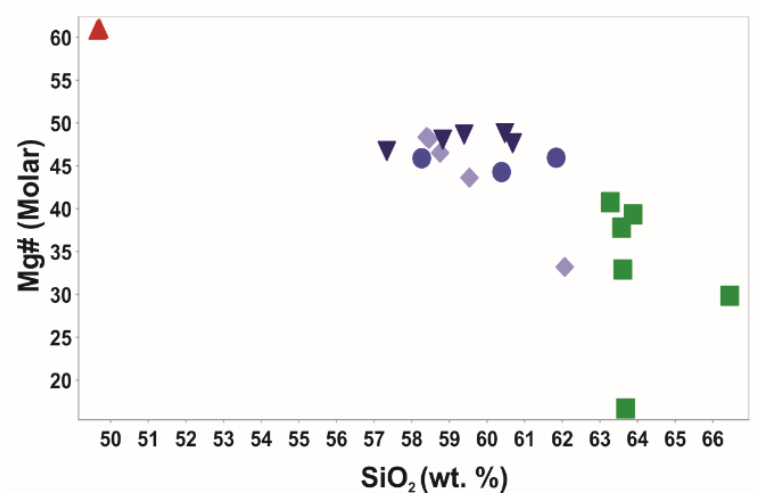

Figure 9. Mg\# for Maungatautari and Kairangi lavas.

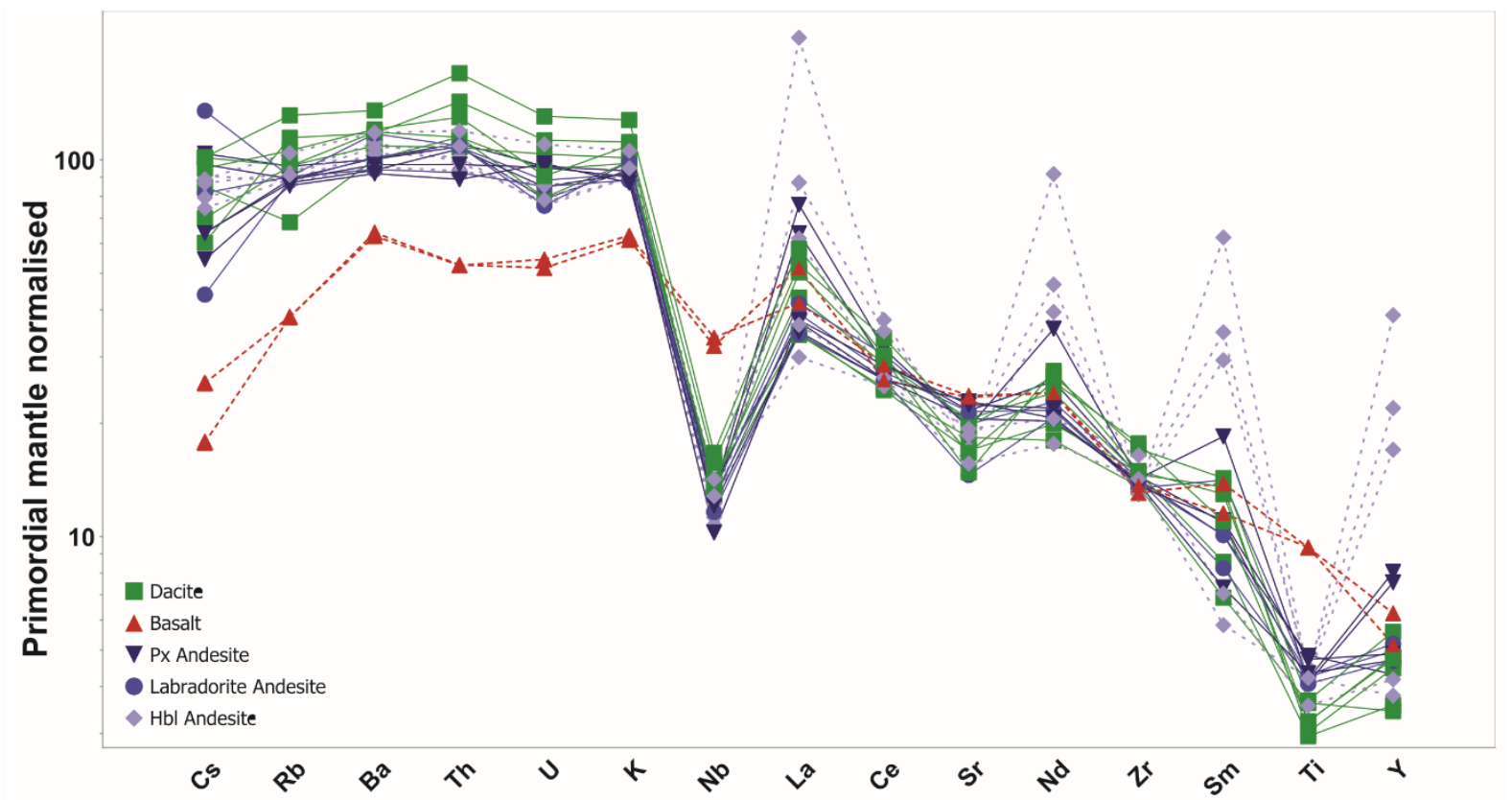

Figure 10. Primordial mantle normalised multi-element diagram for representative Maungatautari and Kairangi lavas. Normalisation factors after Taylor and McLennan (1985). 


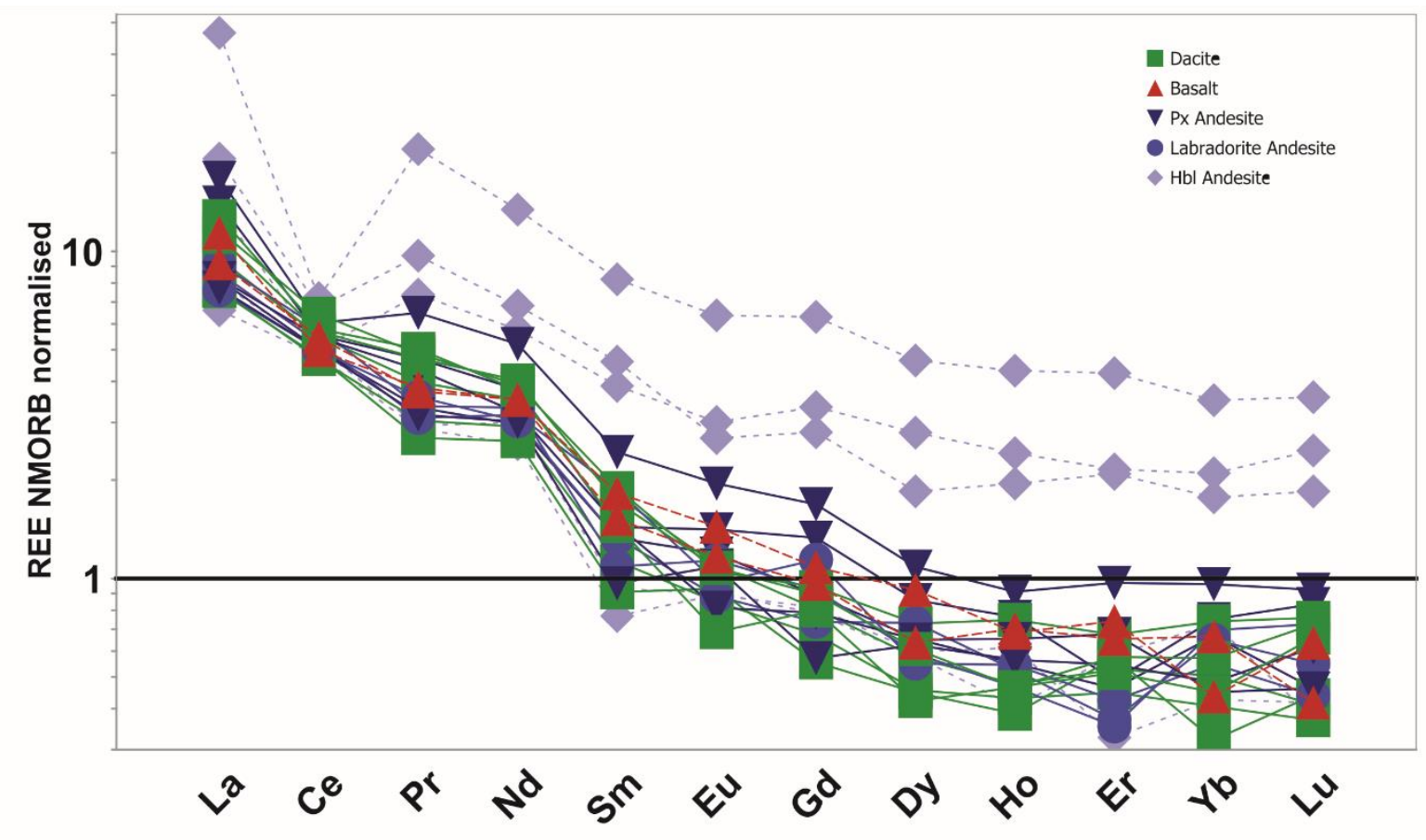

Figure 11. NMORB normalised REE diagram for representative Maungatautari and Kairangi lavas. Normalisation factors after Sun and McDonough (1989). 


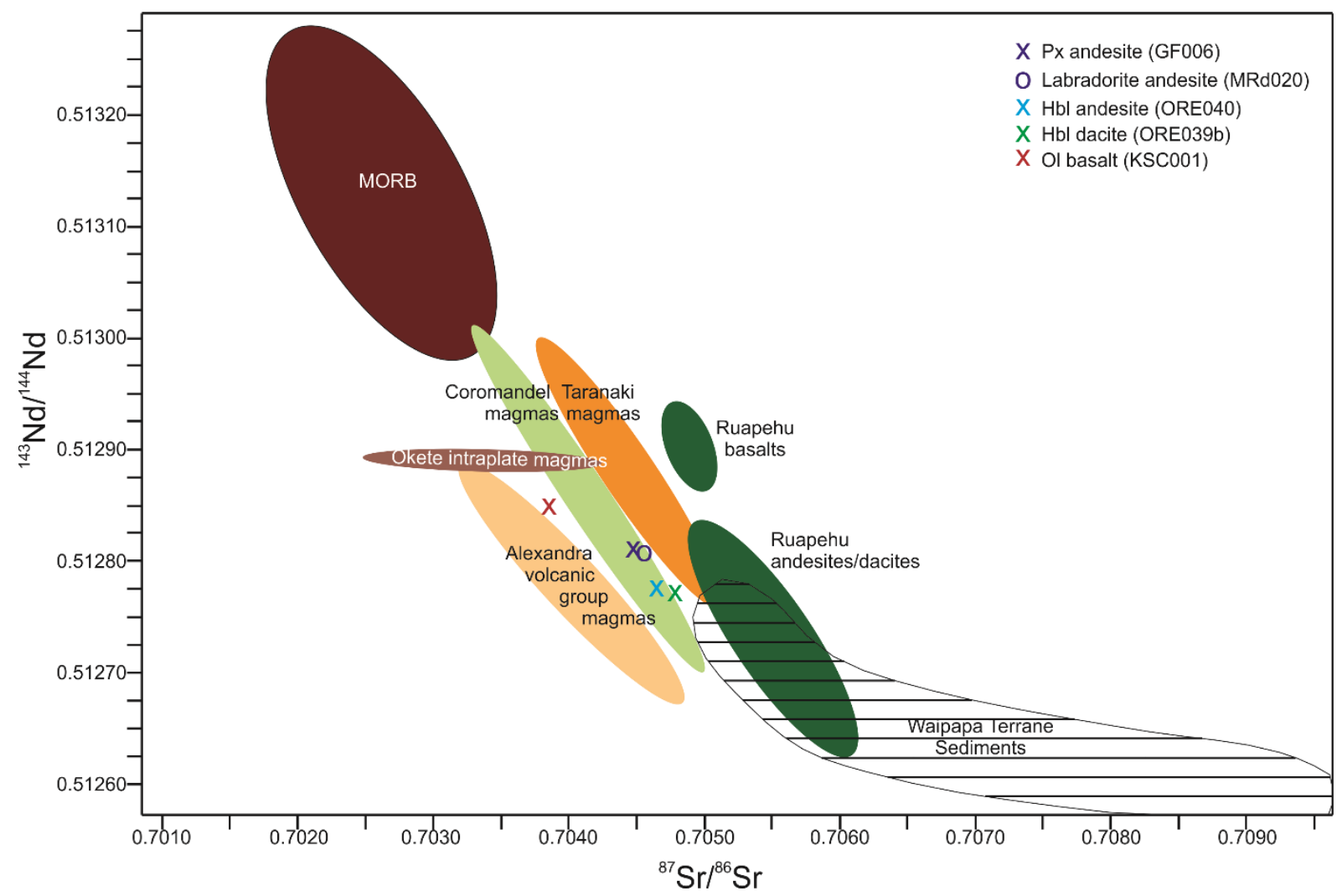

Figure 12. Radiogenic $\mathrm{Sr}$ and $\mathrm{Nd}$ isotopic compositions of representative Maungatautari and Kairangi lavas compared with Ruapehu andesites and basalts (Price et al. 2012), Coromandel Volcanic Zone (Huang et al. 2000), Mt Taranaki (Price et al. 1999), Alexandra Volcanics (Briggs and McDonough 1990) and the Okete Volcanic group (Briggs and Goles 1984). Data for the regional basement terrane (Price et al. 2015) and MORB lavas (Ito et al. 1987) are also included for reference. 


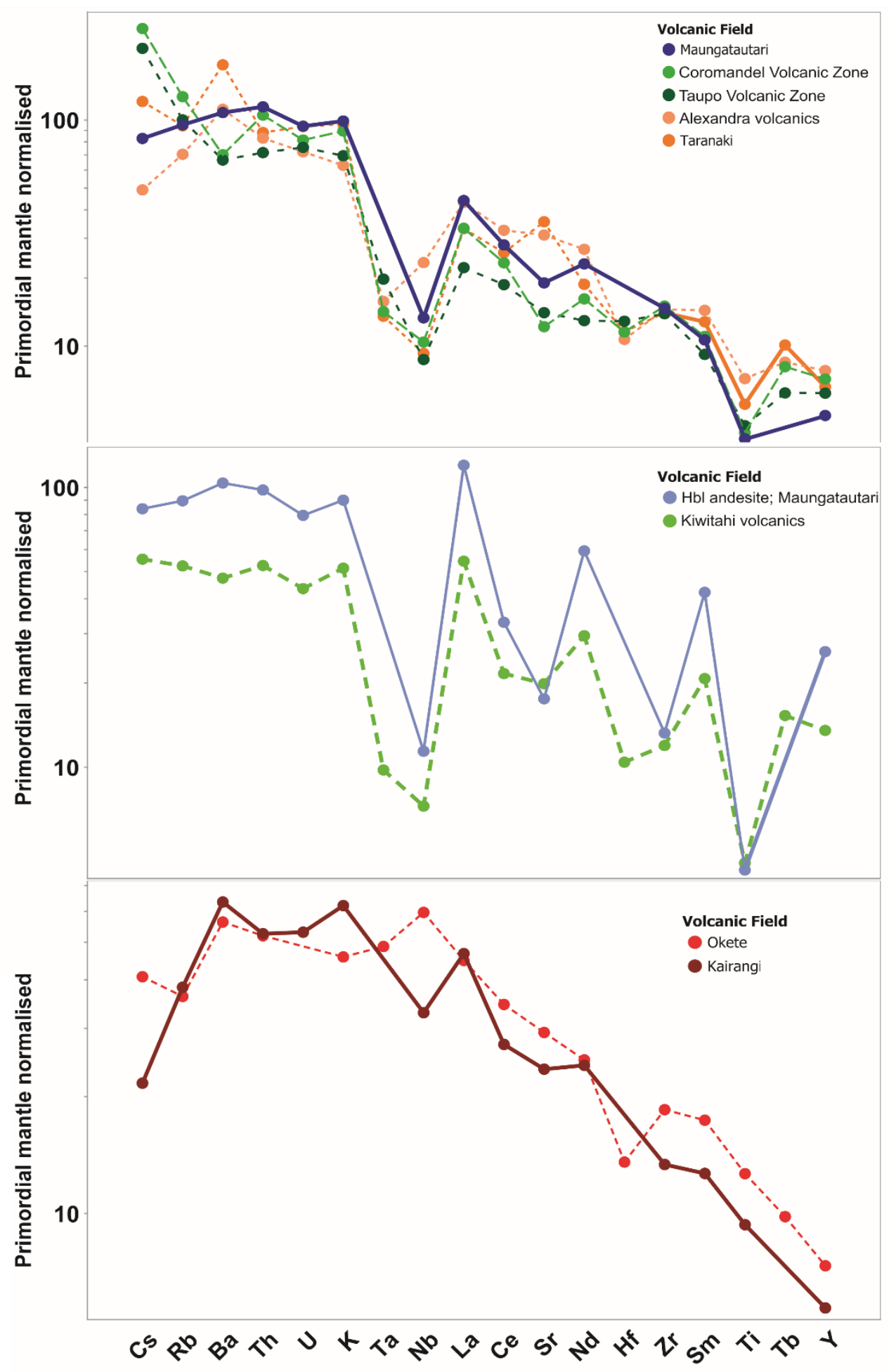

Figure 13. Primordial mantle normalised multi-element diagram for averaged geochemical data from the Coromandel Volcanic Zone (Booden et al. 2012), Kiwitahi (Booden et al. 2010), Ruapehu (Price et al. 2012), Alexandra (Briggs and Goles 1984; Briggs 1986) and Taranaki (Price et al. 1999) volcanic centres and the Okete intra-plate volcanics of the western North Island (Briggs and McDonough 1990). Normalisation factors after Taylor \& McLennan (1985). 


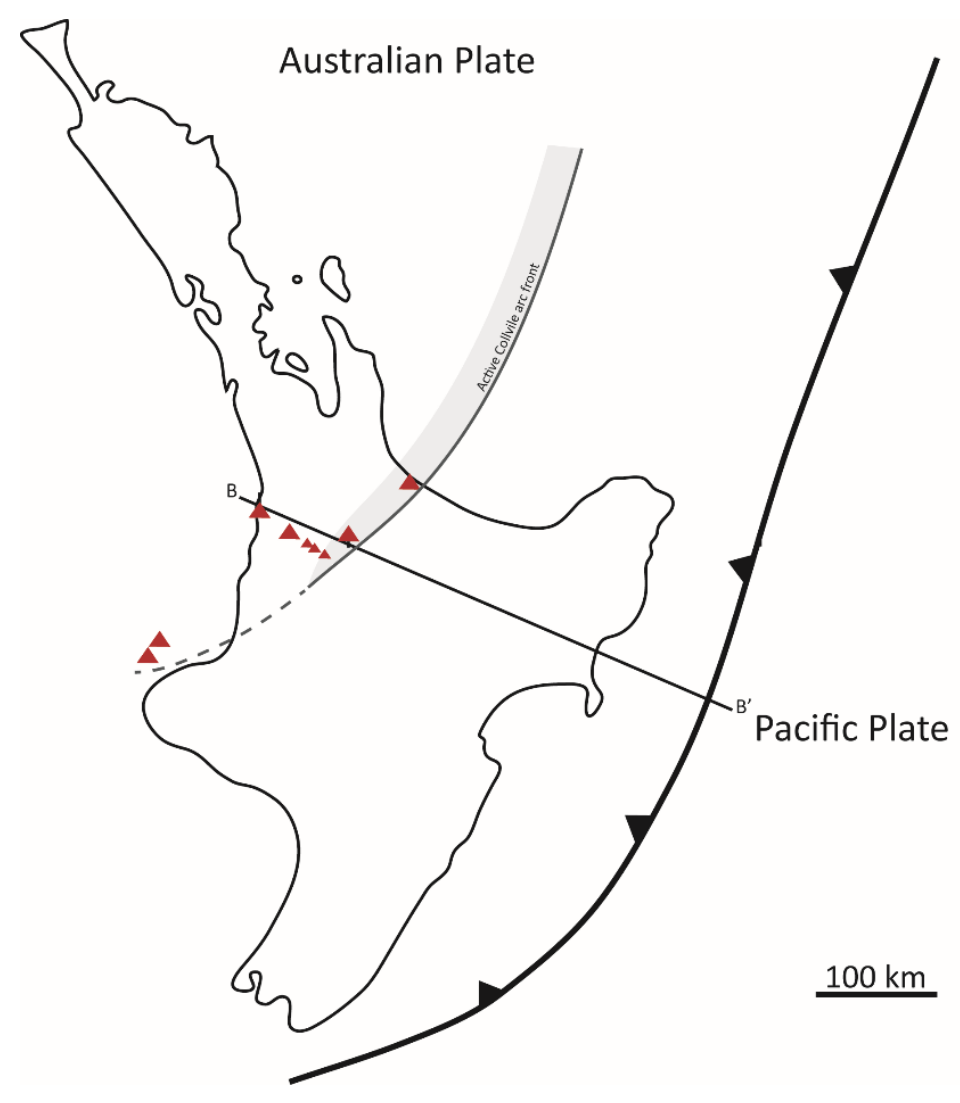

Figure 14. Schematic map showing the estimated position of the Colville volcanic arc at c. $2 \mathrm{Ma}$ and its propagation through the western North Island to include Maungatautari. Active volcanic centres are shown by red triangles. The continuation of the arc to include the western Taranaki Graben Volcanoes (dashed line) remains speculative. 
Booden MA, Smith IEM, Mauk JL, Black PM. 2010. Evolving volcanism at the tip of a propagating arc: The earliest high-Mg andesites in northern New Zealand. Journal of Volcanology and Geothermal Research. 195(2-4):83-96.

Booden MA, Smith IEM, Mauk JL, Black PM. 2012. Geochemical and isotopic development of the Coromandel Volcanic Zone, northern New Zealand, since $18 \mathrm{Ma}$. Journal of Volcanology and Geothermal Research. 219-220:15-32.

Briggs R. 1986. Volcanic rocks of the Waikato Region, western North Island, and some possible petrologic and tectonic constraints on their origin. In: Smith IEM, editor. Late cenozoic volcanism in New Zealand. Wellington, New Zealand: The Royal Society of New Zealand Bulletin 23; p. 76-91. Briggs RM, Goles GG. 1984. Petrological and trace element geochemical features of the Okete Volcanics, western North Island, New Zealand. Contributions to mineralogy and petrology. 86(1):7788.

Briggs RM, McDonough WF. 1990. Contemporaneous convergent margin and intraplate magmatism, North Island, New Zealand. Journal of Petrology. 31(4):813-851.

Huang Y, Hawkesworth C, Smith I, van Calsteren P, Black P. 2000. Geochemistry of late cenozoic basaltic volcanism in Northland and Coromandel, New Zealand: implications for mantle enrichment processes. Chemical Geology. 164(3):219-238.

Ito E, White WM, Göpel C. 1987. The O, $\mathrm{Sr}, \mathrm{Nd}$ and $\mathrm{Pb}$ isotope geochemistry of MORB. Chemical Geology. 62(3-4):157-176.

Jochum KP, Nohl U, Herwig K, Lammel E, Stoll B, Hofmann AW. 2005. GeoReM: A new geochemical database for reference materials and isotopic standards. Geostandards and Geoanalytical Research. 29(3):333-338.

Price R, Gamble JA, Smith IE, Maas R, Waight T, Stewart RB, Woodhead J. 2012. The anatomy of an andesite volcano: a time-stratigraphic study of andesite petrogenesis and crustal evolution at Ruapehu Volcano, New Zealand. Journal of Petrology. 53(10):2139-2189.

Price R, Mortimer N, Smith I, Maas R. 2015. Whole-rock geochemical reference data for Torlesse and Waipapa terranes, North Island, New Zealand. New Zealand Journal of Geology and Geophysics. 58(3):213-228.

Price RC, Stewart RB, Woodhead JD, Smith IEM. 1999. Petrogenesis of high-K arc magmas: Evidence from Egmont Volcano, North Island, New Zealand. Journal of Petrology. 40(1):167-197. 